\title{
Da teoria à prática: várias "formas" de poesia como reinvenção
}

\author{
Chimena Barros da Gama (FAPESP)
}

RESUMO: No estudo da poesia, algumas reflexões parecem opostas, quando, na verdade, a crítica pode ganhar se as utiliza de modo adequado ao que o poema pede. Propomos uma breve reflexão acerca das idéias teóricas de Paul Ricoeur sobre a metáfora e uma união destas com análises baseadas em Roman Jakobson. Refletimos, sobretudo, sobre a possibilidade de olhar o poema por todos os lados, não excluindo nenhuma das abordagens apresentadas por esses autores.

PALAVRAS-CHAVE: poesia, Paul Ricoeur, Roman Jakobson, som, sentido.

De início, esclareçamos o que é considerado aqui "poesia como reinvenção". É pensar o texto poético através do olhar profícuo de Paul Ricoeur, tomando-o como uma nova visão da realidade, na esteira ricoeuriana da mímesis aristotélica. Para o pensador francês, a metáfora, sobre que se debruçou exaustivamente, é a "pedra de toque do valor cognitivo das obras literárias" (2000a, p.57), assim, esse "valor cognitivo", o dar-se como conhecimento, está relacionado à metáfora que pulsa no interior do poema, e é "viva"; inovação que nos revela "um mundo outro que corresponda a outras possibilidades de existir" (2000b, p.350). E se a metáfora é, como também acredita o autor, uma miniatura do poema, ou de toda a sua ambigüidade (2000b, p.150), nesse sentido a poesia é reinvenção como a metáfora o é.

Cumpre salientar que não somos seguidores de uma teoria (ou, neste caso, filosofia) ricoeuriana, e nosso contato com o autor restringe-se à Teoria $d a$ Interpretação (obra publicada em 1970) e A Metáfora viva (de 1975), o que é escasso, perto de toda obra do pensador. Somos, sim, leitores de poesia, e foi em busca de reflexão mais profunda a respeito da criação metafórica que chegamos recentemente a Paul Ricoeur.

Chamou-nos a atenção o extenso diálogo que ele empreendeu com várias ciências, da Lingüística à Psicolingüística, com a Retórica e a Semiótica. Tudo para expor o que, grosso modo, resumimos em duas premissas básicas: a metáfora é o fruto 
de uma "predicação impertinente" (RICOEUR, 2000b, p.10) e, assim, funciona dentro e pelo enunciado, sendo, portanto, conseqüência de um encontro de palavras - ou melhor, de uma tensão entre elas -, e não da substituição em um único léxico; e através dessa tensão, mostra-se uma face desconhecida da realidade, cabendo no conceito de mímesis aristotélica, de que falaremos adiante. Das duas afirmações, o autor concluiu o que afirmávamos há pouco: a literatura tem um valor cognitivo - e ontológico. Eis as dimensões a que Ricoeur leva a poesia.

Embora no presente trabalho não olhemos, nos textos poéticos, exatamente para a questão metafórica - ou talvez até a busquemos, mas por caminho paralelo ao de Ricoeur -, é válido refazer um pouco do seu percurso teórico, a fim de que cheguemos às dúvidas e reflexões que nos trouxeram ao presente texto.

Que a metáfora se dê na instância do discurso (frase ou enunciado), pressupondo uma predicação insólita, em vez de ser um poder do signo isolado, parece-nos certo. Nos célebres versos de Camões "Amor é fogo que arde sem se ver / é ferida que dói e não se sente / é um contentamento descontente" (p.982, p.155), a força metafórica surge, com a menção ao amor de uma maneira até então inédita. A tópica do sentimento amoroso era então recorrente, mas o "ver como" camoniano, as associações paradoxais que faz acerca do sentimento, faz a grandeza do poema. É por isso que o poeta lusitano do século XVI permaneceu, enquanto tantos outros poetas, seguidores de uma retórica engessada, passaram ${ }^{1}$. Tanto em Camões como em um poeta pouco conhecido do século XX, português como o autor dos Lusíadas, João José Cochofel, é fato que seja na junção de palavras que até então não tinham estado juntas e daquela maneira nova, que a metáfora se dá: "em ti é a tarde que afago / e o sol dos olhos e dos cabelos" (1988, p.70), diz-nos o sujeito-lírico. Há palavras no enunciado que consideramos, como Ricoeur, "focos" (para usar terminologia que o próprio autor emprestou de Max Black); no caso de Cochofel, "tarde" e "sol" surgem como os focos metafóricos, mas a invenção só se dá pela sua inserção no "quadro" - verso, frase, poema - e relação com as outras palavras; por si só, elas não têm valor metafórico. Assim, com os dois exemplos, resumimos muito brevemente como se dá a metáfora no e pelo discurso.

Quanto ao outro princípio de Ricoeur - a questão da mímesis aristotélica no âmago da metáfora, também nos parece muito pertinente. Tanto nas afirmações 
inseridas no terceiro ensaio da Teoria da Interpretação e, mais profundamente, na Metáfora Viva, o autor francês revela sua filiação à filosofia do autor da Retórica, propondo-nos, no entanto, uma reflexão e revisão da questão da imitação.

Retomando o pensador grego, o autor francês confirma o princípio da mímesis, inclusive na lírica. Explica-nos, ainda no início de seu livro de 1975 (“Estudo I”), que é na relação entre o mythos("enredo" ou "fabulação") e a imitação, na tragédia, que podemos pensar o gênero poético. Segundo Ricoeur: "Entre o mythos e a tragédia, já não há somente uma ligação entre meio e fim, ou entre a causa natural e o efeito, mas uma ligação de essência [...]” (2000b, p.63). Com efeito, para o mythos confluem outras categorias da tragédia, enumeradas por Aristóteles (2003, p. 111), e é também nele que se dão as "ações", objetos das imitações. É expressando-se assim que o pensador grego chega à conhecida conclusão em relação à importância da "verossimilhança" (2003, p.115). Ricoeur ainda nos lembra que "não há mímesis senão onde há um "fazer" (2000b, p.69) e, sob essa definição, refuta a noção de mímesis como "cópia": ela não copia; faz. Para concluir suas reflexões no estudo primeiro de A Metáfora viva, seu autor efetua então um paralelo entre a noção aristotélica de "elevação" pela mímesis, na tragédia, que seria uma "reordenação das ações humanas" (2000,b, p.69), e a metáfora, que, enquanto renovação, traz algo novo, "reordena" de alguma maneira o mundo: "a imitação é a um só tempo um quadro do humano e uma composição original" (2000b, p.69), e é assim que Ricoeur vê também a metáfora quando "viva".

Muitas páginas depois, já no sétimo estudo inserido no livro, as noções aristotélicas são retomadas, e desta vez em comparação com o que se dá propriamente na linguagem poética. Com efeito, comparando o mythos (que vimos ser essencial à tragédia) ao "estado de alma" essencial à lírica, o estudioso da metáfora chega a uma definição de "mímesis lírica", que tem seu fulcro exatamente no "ver como", ato primeiro da ação metafórica ${ }^{2}$ (2000b, p.374). Mas se é próprio à definição do lírico seu caráter individual, interiorizado, podemos dizer que é na tentativa de recriar esse "estado de alma" - o mythos lírico - que o poeta chega à invenção metafórica mímesis lírica, o "ver como" que coloca a poesia no campo do "possível verossímil".

É preciso lembrar que, na perspectiva ricoeuriana, essa configuração da mímesis lírica é também aberta ao mundo, mas através do que o autor chama de "referência de 
segundo grau", que comporta, na economia do discurso poético, a relação com o mundo; não um mundo factual ou descrito (o da "referência lateral"), mas significado, pois toda poesia porta algum sentido. Essa questão importa para que compreendamos porque diz Ricoeur que "O paradoxo do poético reside inteiramente no fato de que a elevação do sentimento à ficção é condição de sua manifestação mimética. Somente um humor mitizado abre e descobre o mundo" (2000, p.374); na lírica, a "ficção do mood" é o que importa, mas voltada para o mundo (ou para o real, se a palavra não for excessivamente problemática).

Acerca do paralelo entre a mímesis trágica aristotélica e a lírica, ele é também feito no ensaio do crítico brasileiro José Guilherme Merquior, "Natureza da Lírica". Para ele, "A lírica é [...] uma forma de imitação" (1997, p.17) e é pelo aspecto formal da linguagem que a poesia lírica imita o mundo externo, e, assim, ele chega à expressão “mimese interna" (1997, p.23), recorrendo aos pressupostos de Roman Jakobson, entre outros, da ênfase ou conceito de dominante da mensagem no texto poético (1997,p.24); e da questão das "equivalências" das palavras em sua seqüência no poema. (1997, p.26).Por isso, Merquior refere-se, no início do ensaio, à importância, na lírica, da “carne das palavras" (1997, p.17).

Ademais, o autor brasileiro assemelha-se a Ricoeur ao abordar a lírica em termos de "atuação da consciência reflexiva, interiorizante [...]" (1997, p.25) - lembremo-nos de que o pensador francês alude ao "estado de alma", ou mood, termo emprestado de Northop Frye, constituinte da lírica. Porém, a ênfase que Merquior dá, na esteira de uma teoria Jakobsoniana, à mencionada "carne das palavras" (1997, p.17) ou à estrutura interna da lírica, tem um enfoque diferente daquele do autor francês. Para Ricoeur, a mímesis lírica está na invenção metafórica, na construção da metáfora viva - e não na estrutura poemática.

Entretanto, o autor da Teoria da Interpretação cita Jakobson em vários momentos de seus dois livros aqui estudados, mas sua perspectiva é outra: constatando que os pressupostos teóricos do pensador russo incidem sobre "a quase-corporeidade da mensagem" (RICOEUR, 2000b, p.225), e que esta é vista como uma oscilação entre som e sentido, o filósofo francês tenta mostrar o enraizamento dessa idéia numa teoria 
do signo, que se opõe à sua perspectiva semântica da frase. Do mesmo modo, expondo a afirmação de que

na função poética [jakobsoniana] a equivalência é promovida ao plano de procedimento constitutivo da seqüência e, assim, a recorrência das mesmas figuras fônicas, as rimas, os paralelos e os outros procedimentos aparentados induzem de alguma maneira a semelhança semântica. (2000b, p.225)

Ricoeur não chega - neste momento - a opinar claramente sobre a questão sonora na poesia, mas já é previsto, para quem leu sua obra (em que ele expõe idéias, encontra seus problemas e coloca a sua, como numa dialética), que sua opinião é contrária.

Essa postura é evidenciada na abordagem da imagem. Analisando o que chama de "momento sensível" da imagem poética, o autor afirma que este se encontra na metáfora, vista através de sua teoria semântica, e sentencia: "o ato de ler atesta que o traço essencial da linguagem poética não é a fusão do som com o sentido, mas a fusão do sentido com um fluxo de imagens evocadas e ativadas [...]" (2000b, p.324), afirmação a qual faremos uma observação: o autor refere-se ao "traço essencial" - então talvez o par som e sentido tenha importância secundária no ato poético. Mas, como se dará o que ele chama de "evocação ou ativação das imagens"? Elas não podem ser reforçadas pela reiteração sonora? Segundo Ricoeur, "O poeta é o artesão que suscita e modela o imaginário pelo simples jogo da linguagem" (2000b, p.323). E, perguntamos novamente, ao "jogo da linguagem" não pode estar relacionado seu aspecto formal?

Ainda para Ricoeur, também a imagem associa-se ao "ver como" que faz parte do processo metafórico (é dele inseparável, na verdade): “ver como é a relação intuitiva que mantém juntos o sentido e a imagem" (2000b, p.324) e ele é "metade pensamento e metade experiência" (2000b, p.325). Ou seja, a imagem está já na associação primeira empreendida pelo olhar poético, e não apenas no texto pronto.

É preciso, por fim, mencionar que, não tendo em conta a solidariedade entre som e sentido no interior poemático - e, portanto, não considerando a questão do que seria uma espécie de "imagem acústica" - o autor evoca o "poder pictórico da linguagem" 
(2000b, p.325); sua parte "sensível" é, então, totalmente atribuída ao sentido da visão, associada às artes plásticas e não à música e ao sentido auditivo.

Embora concordemos com várias etapas do pensamento ricoeuriano, é a ausência do seu olhar para a estrutura sonora da lírica que nos causa certo desconforto. Não pretendemos afirmar que o som equivale ao sentido, ou o cria, mas que, em certos poemas, pode reforçá-lo, sobretudo depois do acontecimento da consciência da linguagem que se deu na história da poesia, fato relacionado à Modernidade poética. Nossa perspectiva é alimentada pela idéia de que alguns poetas podem sim utilizar certas particularidades sonoras da palavra para enriquecer o sentido do poema, sua referência segunda e até sua metafórica. Provavelmente o enfoque ricoeuriano é o do filósofo que quer, na esteira de sua filiação filosófica, pensar a poesia - através da metáfora - e, na verdade, toda a literatura, com um alcance de tonalidade ontológica e, afastado de questões estruturais. No entanto, a estrutura não pode corroborar um sentido, a construção sonora não enriquece amímesis?

Como se sabe, há poetas que se dedicam mais à melopéia, como lembra Ezra Pound (1997, p.63), construindo seu texto poético não apenas em termos de versificação ou ritmo, mas também atentando para cada pequena parte de seu verso, inserindo nele assonâncias, aliterações, recorrendo à rima de maneira tão rica quanto à criação metafórica. Sobretudo com o Simbolismo - corrente literária em que certamente Jakobson encontrara terreno fértil para suas observações - o "ver como" metafórico também se potencializou no som, no "ouvir como" ou na própria capacidade de, através da recorrência, criar na mente do leitor uma espécie de imagem motivada pelo som. Paul Verlaine seria o caso mais emblemático.

Não obstante, nem todos os poetas filiam-se a essa tradição da motivação sonora, sendo alguns mais imagéticos. São estilos diferentes. Em outros casos, o mesmo poeta ora é mais sonoro, e faz um "jogo com a linguagem” em que o som parece "imitar" o sentido; ora o é menos. Certo é que todo poeta busca a harmonia sonora, ainda que esta não reflita sobre a significação total. Fernando Pessoa, por exemplo:

[54]

Que morta esta hora! Que alma minha chora Tão perdida e alheia? 
Mar batendo na areia,

Para quê? Para quê?

Na alva areia batendo?

Só isso? Não há

Lâmpada de haver -

Um - sentido ardendo

Dentro da hora - já

Espuma de morrer?

(1999, p.18)

As principais metáforas do poema, aquelas que são vivas, estão nas expressões "Lâmpada de haver" e "sentido ardendo/ dentro da hora", que no conjunto da composição inserem o questionamento sobre o tempo, tão cantado pelos poetas, sempre de maneiras diversas. Porém, até mesmo na expressão mais corriqueira nele inserida, a repetida questão "Para quê? Para quê?" não podemos pensar que, no som plosivo do "p" e seco do "k", está a violência do mar batendo na areia? Note-se que este verso "trunca" o ritmo que até então era fluido. E mais: a repetição não parece imitar esse reiterado movimento do mar na areia? E é, em sentido mais profundo ainda, a repetição das horas. Trata-se de uma reiteração sintática e também sonora, do som do mar que se repete cada vez que ele "bate na areia".

Caso talvez mais emblemático do que chamamos "imagem acústica" está na obra de Camilo Pessanha, que, como simbolista, pareceu saber como quase nenhum outro poeta lusitano, o segredo de se despertar a "mímesis" pelo som. Leiamos um soneto do autor:

Foi um dia de inúteis agonias,

- Dia de sol, inundado de sol.

Fulgiam nuas as espadas frias.

- Dia de sol, inundado de sol.

Foi um dia de falsas alegrias.

- Dahlia a esfolhar-se o seu molle sorriso.

Voltavam os ranchos das romarias.

- Dhalia a esfolhar-se, o seu molle sorriso.

Dia impressível mais que os outros dias.

Tão lucido, tão pallido, tão lucido!

Diffuso de theoremas, de theorias...

O dia futil, mais que os outros dias,

Minuete de discretas ironias... 
Tão lucido, tão pallido, tão lucido! (1995, p.100)

Ao lermos o poema, percebemos um ritmo lento, como que mole. Pela sua estrutura sintática (poucos verbos), o que nos "saltam" são impressões desse "dia impressível", como o próprio poema diz. Com efeito, as sensações que nos deixa, não se dão apenas pela metaforização, mas também pelas repetições sonoras: a importante palavra "dia", por exemplo - foco do poema, e da atenção do eu-lírico, ressoa em nossos ouvidos não apenas por sua repetição (ela aparece seis vezes na composição), mas também pelas rimas internas que com ela formam outras 7 palavras ("agonias", "frias", “alegrias", "romarias", "theorias", "ironias", "fulgiam"). Assim, a reiteração sistemática do hiato "ia", "ia", "ia", torna-se monótona aos ouvidos, dando a impressão do dia fútil cantado pelo poeta. O som em si, pode parecer, pela abertura do “i”, alegre, mas é sua repetição exaustiva que reforça a certa idéia de mesmice.

Lembramos ainda que os estribilhos - repetições de versos inteiros, que são 3 dão-nos a mesma impressão sonora que a outra repetição descrita; e a escrita das palavras "Dahlia" e "molle", num mesmo verso, quase nos impulsiona a lê-las com mais vagar, beirando a inércia do "dia". Aliás, essa alteração ortográfica tão freqüente na Clepsidra, além de ressaltar certa "raridade" da palavra, torná-la incomum, reflete na pronúncia, no som, dando-lhe importância. E o que dizer da aliteração em "l" nos versos em que surgem "Dahlia", "esfolhar-se", "molle”, consoante líquida que soa "languidez"? A salvação para essa quase liquidez do dia, essas "inúteis agonias”, talvez estivesse na lucidez, nos versos em que surgem as expressões "tão lúcidos" (aqui, cheios de luz), mas, confrontando ao termo a palavra "pálido" (na composição, sem acento e com dois "l"s), que lhe segue, o poeta mostra-nos uma alternância semântica entre luz (lucido) e falta de cor (pallido), oposição que também parece nos ser sugerida na alternância de vogais acentuadas, cujos sons são tão distintos, nas palavras: "lucido/ pallido", ambas proparoxítonas.

Sobre este e vários poemas de Pessanha, é certo dizer que o som parece tanto motivar a significação - "impressiva", neste caso - quanto o enunciado metafórico; não o som de uma palavra, ou de várias que se juntam a esmo, mas de palavras que dependem umas da outras, constituindo um discurso - poético - que se apresenta 
inseparável de sua matéria sensível: o som. E não podemos mesmo dizer que é possível se chegar a uma "imagem acústica" desse "dia" cantado pelo autor de Clepsydra?

Sentimo-nos então tentados a afirmar que todo poeta, quando se atém às minúcias da potencialidade sonora das palavras combinadas, parece querer mesmo aproximar som e sentido, e metaforizar a significação total de sua composição também pela matéria auditiva - tanto quanto pela construção da metáfora pulsante. O que não saberíamos dizer é se somos condicionados a relacionar assim o som com o sentido pelo fato de o sentido nos surgir primeiro, ou se foi a própria estrutura sonora que o reforçou, que nos impulsionou a pensar o poema como ele nos parece, conforme o pensa Jorge L. Borges: "suspeitei muitas vezes que o sentido é, na verdade, algo acrescentado ao verso" (2000,p.89).

E não acontecerá o mesmo com a seqüência (dividida em dois versos) de Augusto dos Anjos “A lâmpada a estirar línguas vermelhas / Lambe o ar." (1978, p.138), em que a aliteração da consoante líquida "l”, aliada às nasais "m" e " $n$ ", nos dá uma impressão do movimento sinuoso da "luz/língua", e a assonância em "a", aberto, a extensão dessa língua, nesse "quarto minguante" em que lucidez e loucura se misturam? $?^{\underline{3}}$. Os versos estão no longo poema "Tristezas de um quarto minguante", e esse é um momento raro ali, em que o autor do Engenho Pau d'Arco "imita" pelo som, o que destaca os versos dentro da composição.

Outro não é o exemplo da nossa Cecília Meireles, cujos versos são, em vários momentos, música para os nossos ouvidos, e, em alguns deles, a escolha das palavras aparentemente pela sonoridade das consoantes e vogais e pelos acentuação - sugerem as imagens que as metáforas criam. Exemplos são muitos, mas podemos citar alguns versos de "Madrugada no campo" (Mar Absoluto), com suas imagens de um arrozal particularmente poético, que nos passa a impressão de suavidade não só devido à presença repetida de palavras como "doçura", "seda" e "cristal", mas também pela festa sonora de fricativas (“f”, "v", "s" e "z" - sibilantes) e vogais “a", “e” e "i”, que dominam os versos: "Com que doçura esta brisa penteia / a verde seda fina do arrozal / [...] Com que doçura a transparente aurora / tece na fina seda do arrozal / aéreos desenhos de orvalho [...] Com que doçura as borboletas brancas/ prendem os fios verdes do arrozal"; "suspiro de cristal", "íris de cristal", "anis em cristal"; harmonia suave 
apenas quebrada na última quadra, quando a imagem do pássaro caído no arrozal traz uma seqüência da vogal fechada "u”: “- Caído céu, flor azul, estrela última/ súbito sussurro e eco de cristal”. (MEIRELES, 1985, p.227)

Em outros casos, poetas criam uma espécie de paradoxo entre o som e o que dizem, e o extrato sonoro evidencia o que está escondido no poema, como no verso do autor português Carlos de Oliveira: "mulheres da monda mondam na maré” (1992, p.34), em que, embora a imagem, descritiva aqui, nos mostre um movimento brusco, com freqüência, rápido e repetitivo (mondar é cortar ervas ou ramos), os sons nasais aliterados em "m" e " $n$ " dão ao verso certa moleza e languidez. Porém, essa sonoridade explorada ao máximo antecipa o sentido proposto pelo poeta, pois, em seguida, tanto a terra - a "planície" por ele cantada - quanto as "mulheres" do poema, surgem como cansadas, sonolentas: aquela "aquieta-se em modorra", enquanto estas têm olhos que "gotejam de sono". O movimento de "mondar", portanto, aparece no verso citado em tensão com o som das nasais, talvez exatamente porque a imagem, demasiado descritiva, não queira ser tão fiel ao quadro, mas sugere já seu efeito (mondar/ cansar).

Por fim, tomamos outro exemplo de um poeta português do século XX: António Gedeão. Em seus três primeiros livros, são vários os momentos em que o autor recorre à cadência sonora, ao ritmo e a figuras como aliteração e assonância, o que também por vezes nos parece causar uma imagem acústica. Ficamos com os versos "duros", "secos" do poema "Escopro de vidro". É uma composição que metaforiza, toda ela, a luta do poeta com as palavras e sua atividade, que parece passar despercebida. Na última estrofe, lemos os seguintes versos:

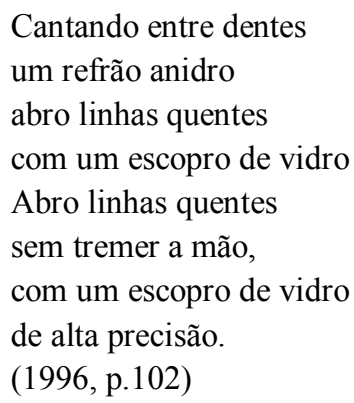

A métrica é curta - são redondilhas menores - e aproxima os sons, concentra-os, de um verso a outro. E esta concentração acontece, sobretudo, nos muitos encontros 
consonantais em "r": "entre", "refrão", “anidro", “abro", “escopro", “vidro", “abro" (novamente), "tremer", "escopro", "vidro" e "precisão", que parecem até mesmo dificultar a leitura do poema - a mesma dificuldade que o eu-lírico encontra para "abrir as linhas quentes", manejar o "escopro" e conseguir cantar esse "refrão" (que é "anidro": sem água). Assim, essa concentração de sons nos sugere a mesma dificuldade que o poeta tem ao manejar o poema. Notemos ainda que, para que a estrofe não se apresente totalmente "seca", ele alterna os muitos encontros consonantais com sons nasais, que lhe dão um pouco mais de leveza, e afastam a pronúncia da dificuldade de uma espécie de "trava-línguas".

Pois bem: com os exemplos, constatamos que essa espécie de "imitação" pelo som pode não se dar no poema todo (por isso Pessanha se nos apresenta com tanto êxito), encontrando-se, porém, em momentos importantes das composições. E, embora tenhamos exemplificado principalmente com casos de assonância e aliteração, a própria alternância de sílabas tônicas e átonas em um poema pode indicar semelhança com aquilo que o poeta nos expressa, bem como a rima faz-se um poderoso modo de aproximações significantes e significadas.

O som, então, "imita"? Não: é a lírica que é mimética, em todos os seus "níveis" (fônico, sintático, semântico, etc.) Mas o som harmoniza a estrutura, e esta é uma parte importante da composição, que reforça seu sentido, e é também reforçada por ele. Diríamos que o estrato fônico contribui para a economia do poema, e para sua inteligibilidade.

O fato é que concordamos com Paul Ricoeur quando ele afirma que a "fusão do som com o sentido" não é o "traço essencial" da linguagem poética, em afirmação já citada. É uma possibilidade da lírica, pois se lhe fosse essencial, teríamos que renegar obras de autores em que esse tipo de poética não é notória. Da mesma forma, a palavra, por si mesma, independente, não tem poderes sonoros-imagéticos, mas apenas no todo poemático, combinada a outras, promove tais acontecimentos.

Parece-nos, pois, que a própria teoria da metáfora como originada e significada na totalidade do discurso é reforçada pelos exemplos, porque, de fato, a tentativa de regulação entre som e sentido só se dá em mais de uma palavra, e não num único signo. 
A contribuição sonora para amímesis está mesmo na totalidade do enunciado, como defende Ricoeur.

Enfim, pensamos que até mesmo das definições jakobsonianas da poesia, no tocante àsrecorrências, tão importantes para a concentração de sentido que o poema nos dá, a idéia de referência ricoeuriana não se afasta totalmente, posto que a elaboração formal também traz à tona esse "mundo do poema", que não é fora da realidade, nem espelho desta, mas sua recriação, renovação. O próprio filósofo francês afirma, na introdução de seu estudo reflexivo sobre a metáfora, que não refuta as teorias lingüísticas, mas vai além dos seus limites $(2000 \mathrm{~b}$, p.10). E, como críticos de poesia, interessa-nos encontrar o que de melhor os dois nos deram: de um lado, pensamos que o metaforizar, no poema, pode estar em todas as escolhas formais também (na configuração estrófica, nas recorrências sonoras, no tom, etc), e não apenas na metáfora em si; por outro lado, tais escolhas não se separam do mundo, mas criam um mundo em que a referência é possível - configurando, assim, a mímesis lírica a que se refere o autor de A Metáfora Viva, retomando perspectiva aristotélica.

Nesse sentido, o autor Alfredo Bosi, em seus estudos sobre o "ser" da poesia, parece conjugar bem alguns postulados relacionados ao formalismo ou ao estruturalismo com idéias semelhantes às de Ricoeur, posto que, assim como o autor de Teoria da Interpretação, o crítico brasileiro pensa o poema em termos de predicação (BOSI, 2000, p.32) e de discurso, de elaboração frasal e não atualizador de potências lexicais, fazendo jus, no entanto, à contribuição de Jakobson para a apreciação do poético: "Que a fórmula de Jakobson seja lida em um registro dinâmico, e não paralisada em compulsiva ecolalia" (2000, p.35), escreveu o autor; e que, acrescentamos, se transforme em uma forma de avaliar a poesia como reinvenção: é o que nos parece possibilitar as aproximações de Jakobson e Ricoeur. E a apreciação crítica do poema só tem a ganhar com isso.

\section{NOTAS}

${ }^{1} \mathrm{E}$ citamos Camões não por acaso: pode haver uma tendência a se pensar que a "metáfora viva" é invenção ou êxito moderno, mas o próprio Paul Ricoeur recorre a exemplos de Shakespeare para referir-se a ela. 
${ }^{2}$ Para Ricoeur, o processo de criação da metáfora não está em uma simples substituição, como acreditaram vários retóricos e outros estudiosos, mas na intuição poética e no "ver como" - expressão que ele empresta do próprio Aristóteles. Assim, o metaforizado não deixa de ser o que é, mas "fica como". Por isso a metáfora é a gênese de uma comparação que, por sua vez, é uma metáfora desenvolvida, e não o contrário como também se vê em estudos vários.

${ }^{3}$ Retiramos o exemplo do longo poema "Tristezas de um quarto minguante".

\section{Referências bibliográficas:}

ANJOS, A. dos. Toda a poesia de Augusto dos Anjos. E um estudo crítico de Ferreira Gullar. Rio de Janeiro: Paz e Terra, 1978, p.138-140.

ARISTÓTELES. Poética. Trad., prefácio, introdução, comentários e apêndices de Eudoro de Sousa. Lisboa: Imprensa Nacional-Casa da Moeda, 2003.

BORGES, J. L. Esse ofício do verso. São Paulo: Companhia das Letras, 2000. BOSI, A. O Ser e o tempo da poesia. São Paulo: Companhia das Letras, 2000.

CAMÕES, L.de. Lírica. São Paulo/ Belo Horizonte: Edusp/Itatiaia, 1992.

COCHOFEL, J. J. Obra poética. Lisboa: Caminho, 1988.

GEDEÃO, A. Poesia Completa. Lisboa: Sá da Costa, 1996.

JAKOBSON, R. Lingüística e Comunicação. São Paulo: Cultrix, 1969.

MEIRELES, C. Obra Poética. Rio de Janeiro: Nova Aguilar, 1985.

OLIVEIRA, C.de. Obras de Carlos de Oliveira. Lisboa: Caminho, 1992.

PESSANHA, C. Clepsydra. Edição crítica de Paulo Franchetti. Lisboa: Relógio d'Água, 1995.

PESSOA. F. Obra Poética. Rio de Janeiro: Nova Aguilar, 1999.

POUND, E. ABC da Literatura. São Paulo: Cultrix, 1997.

RICOEUR, P. A Metáfora viva. São Paulo: Edições Loyola, $2000 \mathrm{~b}$. . Teoria da interpretação. Lisboa: Edições 70, 2000a. 


\title{
"Firma de Poesia": o projeto poético de Haroldo de Campos
}

\author{
Diana Junkes Martha Toneto (UNAERP)
}

\begin{abstract}
RESUMO: A discussão que aqui se propõe volta-se para o estudo da obra de Haroldo de Campos a partir da perspectiva sincrônica de abordagem da história literária que norteou suas atividades. Nesse sentido, poder-se-ia delinear um projeto haroldiano de poesia, cuja visão de modernidade orienta tanto a ruptura de vanguarda quanto a reinvenção do cânone, invariantes de um trabalho ao qual o poeta incorpora distintas dicções, desde o concretismo dos anos iniciais até os diálogos com textos bíblicos e com a ciência, percebido nos últimos poemas. Essas instâncias, todavia, parecem não significar apenas uma sucessão de fases, mas sim o aprofundamento de um modo de conceber a poesia que tem início na década de 1950 e marca-se pela busca da materialidade poética e pela invenção, ao mesmo tempo que revelam a dívida do poeta para com a tradição literária, sobretudo a brasileira.
\end{abstract}

PALAVRAS-CHAVE: Haroldo de Campos; projeto poético; poética sincrônica; tradição; modernidade.

\begin{abstract}
The aim of this article concerns to the Haroldo de Campos 's work analyses, since the synchronic perspective of literary approach. In this sense, it is possible to define a haroldian poetry project which modernity vision orientates the vanguard rupture and the canon reinvention, invariants of a work that coordinate different accents, since the concretism of the first years until the biblical dialogues and science presented in the last texts. These instances, although, seems not a succession of degrees, but more than this, reveals a conception of poetry marked by the search of the poetic word materiality and the inventiveness, at the same time that shows up a sense of poet's gratitude to the literary tradition, specially the Brazilian one.
\end{abstract}

KEYWORDS: Haroldo de Campos; poetry project; synchronic poetics; tradition; modernity.

\section{A Firma de Poesia}

Conta-se que certa vez Oswald de Andrade deu a Augusto e a Haroldo de Campos um livro com dedicatória aproximadamente assim: "Para os Irmãos Campos, Firma de Poesia". Essa dedicatória poderia ser explicada, certamente, a partir de muitas e rememoráveis histórias. Interesso-me aqui, especificamente, pela "Firma de Poesia" e 
pelo que essa colocação implica em termos do fazer poético de Haroldo de Campos. Segundo o Dicionário Novo Aurélio, assim pode-se definir firma:

[Dev. de firmar]. S.f. 1. Assinatura por extenso ou abreviada, manuscrita ou gravada. 2. Ponto de apoio. 3. Estabelecimento comercial ou industrial [...]. 4. JurNome us. pelo comerciante ou industrial (pessoa natural ou jurídica) no exercício de suas atividades; razão social. (FERREIRA, 1999, p. 908).

A definição sugere a polissemia do termo e constitui-se em bom ponto de partida para a compreensão do fazer poético calcado na modernidade desenvolvido pelos poetas concretos paulistas. Se entendida a firma como assinatura, a assinatura da/na poesia, no caso aqui apresentado, pode-se pensar na própria importância da poesia dos irmãos Campos, responsáveis por uma nova assinatura na poesia brasileira, por meio da retomada de muitas das idéias do próprio Oswald. (CAMPOS, 1992, p.231-256). Uma assinatura que se iria inscrever na história da literatura brasileira. Se entendida como ponto de apoio, a firma de poesia revela a própria palavra poética como sustentação da criação via linguagem.

São, entretanto, as duas últimas acepções que parecem melhor servir à compreensão do trabalho inaugurado pelos poetas concretos em meados da década de 1950: a caracterização da firma como estabelecimento comercial, ou, melhor ainda, para o caso criativo de Haroldo e Augusto, estabelecimento industrial, sugere a associação dos trabalhos poéticos dos dois irmãos a um fazer artístico criterioso, um ofício de fato, que visa a uma produção poética.

Esse "estabelecimento poético-industrial" certamente deveria contar com uma razão social - nome ou assinatura do estabelecimento, ou, simplesmente, a razão de ser da poesia, sua função social em termos de revigoração da linguagem e compromisso com a língua, conforme os termos de Eliot. Tal compromisso desdobra-se, evidentemente, na multiplicidade de vertentes criativas em que atuaram (e atua, ainda, Augusto de Campos): da poesia à crítica, passando pela tradução.

Segundo essa perspectiva, o fazer poético de Augusto e de Haroldo assumiria sério compromisso com a palavra poética em termos "sócio-criativos". A novidade e a invenção, bem como a consideração da antropofagia são cruciais para entender seus 
preceitos criativos. A meu ver, entretanto, há mais do que novidade e invenção nos projetos poéticos de ambos, estendidos para além das bordas da Poesia Concreta. Sobretudo, há mais reinvenção e historicidade no projeto de Haroldo de Campos do que se possa supor a partir de uma leitura inicial de sua obra.

Neste ensaio irei ater-me especificamente à obra de Haroldo de Campos. A breve discussão apresentada a seguir ressalta uma possibilidade de estudos críticos acerca de sua obra a partir da perspectiva sincrônica de abordagem da história literária, norteadora de suas atividades. Nesse sentido, pode-se delinear uma leitura da obra haroldiana, cuja visão poética se orienta tanto pela ruptura de vanguarda quanto pela reinvenção do cânone, invariantes de um trabalho ao qual o poeta incorpora distintas dicções, desde o concretismo dos anos iniciais até os diálogos com textos bíblicos e com a ciência, percebido nos últimos poemas, entre outros traços herdados da tradição. Essas instâncias, todavia, parecem não significar apenas uma sucessão de fases, mas sim o aprofundamento de um modo de conceber a poesia que tem início na década de $1950 \mathrm{e}$ marca-se pela busca da materialidade poética e pela invenção, inclusive, e talvez principalmente, na tradição literária. A tensão entre espalhar a novidade e impedir a tradição de cristalizar-se engendra a construção do projeto haroldiano.

\section{O poeta concreto e a tradição}

Desde os primeiros poemas observa-se, em Haroldo de Campos, um profundo respeito e uma "dívida", se é que se pode dizer assim, para com a tradição. A inserção dos textos passados em sua obra dá a ela um caráter de palimpsesto e exige do leitor leitura atenta e muita erudição, posto não serem poucas as citações, as paráfrases e as mais variadas formas de referência ao cânone que surgem em sua obra. Segundo o próprio poeta, este modo de incluir a tradição em seus textos pode ser definido como perspectiva sincrônica da abordagem literária, de acordo com a qual a constituição do presente dá-se em função das escolhas/ reconstruções do passado (CAMPOS, 1997, p.243). Em outras palavras: o retorno ao passado (sincronia) em termos de escolha/ construção de um paideuma, é marcado por uma postura construída no presente que seleciona da série literária aquilo que deve permanecer para possibilitar a construção de uma história plurissignificativa, capaz de tornar contemporâneos "Safo e Bashô, Dante e 
Camões, Sá de Miranda e Fernando Pessoa, Hölderlin e Celan, Góngora e Mallarmé”, poetas concretos porque a palavra em suas obras surge em função poética, palpável e plasticizada, iconizada. (ibid, p.268-269). Para além das particularizações impostas pela história literária diacrônica, o paradigma haroldiano é inclusor sempre, desde que se considerem a inventividade e a ruptura como critério de inclusão.

Há, ainda, outro aspecto importante a ser destacado no que concerne ao trabalho criativo de Haroldo de Campos. Trata-se de considerar todas as vertentes de sua obra (poesia, tradução e crítica) como uma tríade essencial ou, mais do que isso, como unidade orientada pela preocupação com a concreção sígnica. Nesse sentido, é sempre importante lembrar as palavras de João Alexandre Barbosa a esse respeito: "Poesia, tradução e crítica para mim, [...] não são senãopersonae de um criador empenhado em buscar limites (ou as ilimitações?) de uma inserção na história de seu tempo, quer dizer, na linguagem de seu tempo. História e linguagem: passagens" (BARBOSA, 1979, p.20). Destarte, quando se pensa em projeto poético de Haroldo de Campos deve-se pensar nas três vertentes de sua atuação em termos de trabalho com a linguagem e devese pensar que tanto a crítica quanto a tradução são subproduto de uma poética em ação, cuja engrenagem é o pensamento poético e sua preocupação em fazer convergir passado e futuro na linguagem presente, definindo, pois, uma poética da agoridade (CAMPOS, 1996, p.16; CAMPOS, 1997, p.269).

A inserção do poeta na linguagem do seu tempo pode ser compreendida tanto do ponto de vista de sua relação com o cânone universal, quanto do ponto de vista de sua relação com a literatura brasileira; nesse sentido, nota-se a tentativa de estabelecimento de uma busca de suas próprias origens por meio da criação de precursores brasileiros, criação esta que deve aqui ser entendida em termos borgianos (BORGES, 1982, p.226228). O projeto poético de Haroldo de Campos pode, desse modo, ser mais bem precisado quando se assume a importância dos diálogos com a tradição em sua obra, sobretudo os diálogos com a nossa tradição, responsáveis, provavelmente, pela brasilidade operante na recriação que o poeta faz do cânone universal e no modo como se relaciona com o mundo propriamente dito. Apenas a título de exemplo, veja-se o poema abaixo, publicado em Crisantempo (1998, p.89-93): 
MENINOS EU VI

vi oswald de andrade

o pai antropófago em 49

reclinado numa cadeira de balanço

$[\ldots]$

vi ezra pound em 59

na via mameli em rapallo

(tuesday four pm ore sedici)

[...]

vi roman jakobson en la jolla

califórnia ano 66

(a seu lado kristina pomorska loura cabeça altiva)

$[\ldots]$

$[\ldots]$

vi tudo isso e muitas outras coisas

$[\ldots]$

No poema acima, as referências dizem respeito, aparentemente, apenas às várias experiências do poeta, aos amigos que fez e às influências recebidas em sua obra. Tudo isso fica claro pela leitura do fragmento, porém, há mais do que referências; há, sim, a citação direta de Gonçalves Dias e de seu I-Juca-Pirama (2008, p.1149). Para contar o heroísmo do tupi que foi digno de ser morto pelos timbiras, o velho timbira que tudo presenciou aciona a memória e narra, aos jovens índios de sua tribo, o que viu, assim:

X

Um velho Timbira, coberto de glória

Guardou a memória

Do moço guerreiro, do velho Tupi

E à noite, nas tabas, se alguém duvidava

Do que ele contava

Dizia prudente: - "Meninos, eu vi!"

Eu vi o brioso no largo terreiro

Cantar prisioneiro

Seu canto de morte, que nunca esqueci:

Valente, como era, chorou sem ter pejo;

Parece que vejo,

Que o tenho nest'hora diante de mi 
Haroldo de Campos, em seu poema, recria o papel do aedo gonçalvino e conta o que viu; o que diferencia ambos, entretanto, é o fato de o eu-poético haroldiano narrar os próprios feitos do poeta e aqui há, então, uma mistura; o épico não remete tanto à Ilíada ou à Eneida como em Gonçalves Dias (FRANCHETTI, 2008, p. 1113), mas à Odisséia. Como Ulisses, o poeta de "Meninos eu vi", falará de seus feitos e, sobretudo, de suas viagens. De fato, as viagens são tema constante na obra de Haroldo, também caracterizada grandemente pelo épico, configurando-se ambos como suas predileções, ou, mais ainda, suas obsessões. Outro aspecto que merece ser destacado aqui é a parábola haroldiana, pois "Haroldo é o personagem central de suas criações" (VIEIRA, 2006, p.6).

Severo Sarduy percebe cada texto de Haroldo de Campos como parábola da sua escritura, um mapa do Brasil (SARDUY, 1979, p. 123, 125). Em cada texto, poema, transcriação e estudo crítico, a historicidade da obra do poeta configura-se como parábola pessoal e nessa escritura em certa medida confessional (Meninos eu vi) o poeta estabelece uma associação entre sua palavra e os diálogos com a tradição literária, atribuindo supremacia às referências brasileiras. Em certa medida, poderíamos dizer, portanto, que a obra de Haroldo de Campos é confessional: retoma a tradição e seus próprios textos de modo que cada texto seu pode ser visto como acervo dos anteriores; ao mesmo tempo, esse acervo é organizado por um "curador" que tem seu fazer determinado pela literatura e pela cultura brasileiras, especialmente quando transcria os textos da mais alta tradição literária. Um exemplo dessa atitude pode ser extraído de comentário feito pelo poeta:

Aí vou pôr algumas traduções especiais, uma delas uma tradução de Horácio, de uma ode de Horácio, de uma ode famosa que começa assim: "pérsicos odi, puer, apparatus" [...]. A minha tradução retoma Horácio por via de Noel Rosa:

Garçom, faça o favor, nada de luxos persas.

Não me venha com estes 
enfeites de tília.

Rosas? Não quero rosas

se alguma ainda esquiva.

$[\ldots]$

Este tipo de trabalho é um modo de fazer o novo, de fazer Horácio cantar Noel Rosa, por que não? (CAMPOS, 1996, p.24,25).

Ensina Antonio Candido que a literatura afina a nossa visão de mundo, orquestra-a; quer percebamos ou não, ela influencia a nossa forma de conceber o entorno (2004, p.170); claro está, portanto, que Haroldo de Campos não poderia furtar-se aos determinismos da literatura e da cultura brasileiras; por outro lado, como não há fronteiras em termos de arte, já que a obra de arte é aberta (CAMPOS, 1955), a herança universal mescla-se ao olhar marcado pela nossa cultura para definir matizes impressionantes; uma obra única e alicerçada pela vanguarda, mas que tem, nos andaimes da tradição, sua sustentação.

Dada a sua postura vanguardista e a preocupação com a construção do poema como objeto de linguagem, preocupação esta orientada pela função poética jakobsoniana, Haroldo de Campos é normalmente visto, dentro do escopo da literatura brasileira, como herdeiro de João Cabral de Melo Neto; dada a preocupação com a devoração cultural crítica da tradição, estabelece-se um linha sucessória OswaldHaroldo. Todavia, se a antropofagia oswaldiana e o rigor cabralino são invariantes de seu trabalho, as heranças drummondianas e rosianas, a precisão euclidiana, o lirismo de Bandeira, os signos intensos de Sousândrade e muitas outras referências da nossa literatura e de nossa cultura marcam também a obra haroldiana e surgem ora como estudos críticos, ora como aportes da prática tradutória, mas, fundamentalmente, incorporadas aos próprios poemas. Um exemplo muito instigante desses aportes, ou ainda, desses portos para onde convergem os navios criativos de Haroldo, é o poema $A$ Máquina do Mundo Repensada. Nesse poema, o último publicado pelo poeta, a literatura brasileira surge em refrações prismáticas, fundando uma cosmogonia que começa com ares drummondianos e termina retomando o nonadarosiano. 
Não se pode deixar de mencionar neste ponto que o poeta faz a leitura da tradição literária e da história da maneira como faz porque sua leitura é historicamente datada, assim como são historicamente datados os textos com os quais dialoga. À sincronia haroldiana, construída no limiar do século XXI, é preciso acrescer a diacronia dos processos históricos, inclusive aquela que ele mesmo vivencia; esse processo sincrônico-diacrônico permite situar o fazer poético haroldiano (incluem-se neste fazer a tradução e a crítica) como um catalisador de múltiplas experiências culturais e históricas unificadas pela arte poética: poesia, catarse (BARBOSA, 1979, p.18).

O movimento de leitura sincrônico-diacrônico é modelar para a compreensão do direito (humano) à literatura a que todos temos nos moldes suscitados por Antonio Candido no ensaio $O$ direito à literatura (2004, p. 169-192), à medida que incorpora tanto a literariedade das obras, afirmando-as como direito universal, porque dão forma aos sentimentos e nos humanizam quanto se revela como instrumento de compreensão do mundo em que vivemos e, no caso específico da obra haroldiana, da nossa sociedade. A obra de Haroldo toma os clássicos em posição dialógica e é a partir desse diálogo que situa a literatura brasileira e nossa sociedade. Tal movimento dá, ao poeta, oportunidade de inserir-se na linguagem de seu tempo e dá, principalmente, condições para que ele, por meio de sua palavra, pense a nossa sociedade, cumprindo, dessa forma, a razão (social) de ser da firma poética que estabelece com seu ofício de poeta.

A historicidade do projeto poético de Haroldo de Campos não só cumpre importante papel dentro de nossa cultura, pois antropofagicamente revitaliza a literariedade dos textos universais, como também (re)significa a própria experiência de leitura do cânone brasileiro. Para dar conta disso, apóia-se no dialogismo que os clássicos, com sua vocação para o futuro, legaram-nos (BRANDÃO, 1992, p.42). Na cosmogonia criativa de Haroldo de Campos, constelações históricas reluzem por meio da literatura e da informação estética que ela veicula e, por isso, pela potencial capacidade de organização de nosso mundo interior que possibilita e por permitir, também, que na esteira do poeta repensemos nossa relação com a sociedade brasileira, tais constelações históricas significam concretamente, materializadas pela palavra poética haroldiana que não se restringe apenas a seus poemas e faz convergir o passado 
(tradição literária) e a projeção futura (alavancada pelo discurso de vanguarda) para o presente, grande mediador transtemporal do pensamento poético haroldiano.

O pensamento (poético) de Haroldo de Campos ora se aproxima da tradição, inclusive pela forma adotada nos poemas, como em Lamento sobre o lago Nemi, de 1950, republicado em "Xadrez de Estrelas" (1976), ou o já citado poema A Máquina do Mundo Repensada (2000); ora corrompe essa forma e reivindica para a tradição um lugar de (re)significação das experimentações da linguagem fundadas na modernidade por Mallarmé e Joyce, por exemplo. É o caso de ô âmago do ômega, de 1955-1956, também republicado em "Xadrez de Estrelas" (1976) e de Galáxias, escrito entre 19631976, poemas em que se verificam citações de distintos precursores do poeta.

É interessante comentar que em Galáxias, Haroldo, o vanguardista, evoca ninguém menos do que o parnasiano Bilac. "Ora, direis, ouvir galáxias" é o nome do texto elaborado por Haroldo de Campos acerca de seu poema (CAMPOS, 2004, p.119). Do Xadrez de Estrelas que nomeia antologia poética de Haroldo de Campos, retomando Padre Antonio Vieira, a Galáxias, percebe-se nos poemas de Haroldo um eu-poético viajor que no périplo do poema resgata companheiros de viagem, devolve-lhes à vida, não como esta fora, mas como (im)possibilidade de existência no presente assegura que as constelações poéticas permaneçam reluzindo mesmo após a morte das estrelas da tradição que as originaram.

\section{Para ler o projeto poético de Haroldo de Campos: caminhos possíveis}

Um estudo do projeto poético de Haroldo de Campos poderia, pois, ser desmembrado em três partes correlatas. Em primeiro lugar, seria importante identificar e discutir diálogos com a literatura brasileira, estabelecendo quais as invariantes das escolhas do poeta no que concerne ao nosso cânone, ou seja, qual literatura brasileira é resgata por ele. Cabe destacar que, pelo estabelecimento dessas intertextualidades, certamente se estará ampliando a perspectiva sincrônica defendida pelo próprio poeta, pois que a ela serão incorporados, inevitavelmente, fatores como o contexto de produção/recepção das obras referidas, uma vez que estes engendram tanto significados quanto significantes (tão valorizados pela visada vanguardista que marca a obra haroldiana). 
Em segundo lugar, ao mediar essas interfaces entre a obra de Haroldo de Campos e o estudo dos autores e obras brasileiros que ele lê permitiria a análise de suas produções sob ampla perspectiva, destacando-se tanto sua potencial característica para apreender e conhecer a realidade quanto sua potencial força para transformá-la e criá-la, porque como diz Campos deve-se pensar que "[a] poesia engloba uma prática e uma história" (CAMPOS, 1996, p.14). Diante disso, fica claro porque tanto a preocupação com a novidade quanto àquela referente à manutenção da tradição são cruciais para a compreensão do projeto poético de Haroldo de Campos.

Em terceiro lugar, seria interessante averiguar em que medida a presença da história da literatura brasileira que se ergue do seu fazer criativo é crucial para o poeta Haroldo de Campos enquanto instrumento construtivo do mesmo. Uma vez que os diálogos com a tradição são marca da obra haroldiana, resta saber se a literatura brasileira tem peso igual ou maior que o cânone universal em termos da construção da obra do poeta. Seria interessante estimar, por fim, em que medida Haroldo de Campos lê a tradição literária como um contínuo indistinto, "tradição literária", em que tanto o cânone universal como o brasileiro têm papéis iguais, ou se a brasilidade de sua leitura o faz preponderar a nossa tradição e, a partir dos nossos referenciais, é que ele irá valorizar determinado cânone universal.

Como os fragmentos coloridos de um caleidoscópio dotado de dinamismo próprio, a tradição se estilhaça na obra haroldiana para ser, ali mesmo, em seu escopo, restaurada em suas máximas potencialidades, segundo o olhar que lhe atribui um poeta cujo discurso marca-se pela vanguarda, pela antropofagia, pela urgência do "make it new" poundiano e, simultaneamente, devota profunda gratidão aos clássicos.

O projeto poético haroldiano, calcado na construção de um paideuma que é articulado por sua poética sincrônica rompe a linearidade do pensamento positivista com que é tratada a História Literária na maioria das vezes, desse modo, a tradição incorpora-se à obra de Haroldo de Campos em termos sintáticos e semânticos e se mescla ao presente que a restaura, re-inventa, livra-a do inconformismo (BENJAMIM, 1996, p.224). 
O retorno de Haroldo de Campos à tradição assume estatuto de travessia; não só o poeta fala de suas viagens pela voz de seus diferentes eu-poemáticos, aedos de seus poemas e transcriações, como a busca e a invenção de seus precursores constituem-se em etapas de seu percurso de volta às origens. Mas para conduzir este Odisseu a Ítaca merecida é preciso lançar novos alísios à sua poética sincrônica, talvez entendendo que o reconhecimento e a gratidão orientem a necessidade de fazer os textos da tradição sobreviverem; a sobrevivência destes garantiria a escritura da parábola haroldiana, a sobrevivência do próprio poeta e de seu canto órfico.

É porque vai ao Hades que Haroldo (Odisseu-Orfeu) reconhece o que herdou; revê os companheiros, indaga pelo caminho da volta e se percebe disposto a ultrapassar o signo para ouvir o canto arriscado das sereias da tradição ou das sirenes da urbe moderna, como diz em seuFinismundo: a última viagem (1990). É porque vai ao Hades que tenta resgatar e trazer à luz os companheiros, como ensina Donaldo Schüler (1997). Entretanto, diferentemente do Orfeu do mito, Haroldo não volta os olhos, sabe que os companheiros o acompanham; é Odisseu demais para prender-se às imagens dos mortos, precisa viver o luto por eles fazendo-os viver como espectros em si mesmo, em sua palavra marcada de gratidão (MARGEL, 2000; SISCAR, 2000).

Por fim, é porque vai ao passado com os olhos postos no horizonte que o futuro acena-lhe, que o poeta evita seu próprio esfacelamento; costura vozes e cantos, orquestra-os ao seu próprio dizer Ur-poético, presentificado na palavra plasticizada que permeia a materialidade dos signos moventes no universo que fundou. Haroldo sempre soube que viver é mesmo perigoso se a vida não for compreendida a partir da travessia entre o ontem e o amanhã. Para o poeta, viver era simplesmente preciso como risco, nada feito no nada, presente absoluto ou acaso indomável: um lance de $\infty$. 


\section{Referências Bibliográficas}

BARBOSA, J.A. Um Cosmonauta do Significante: Navegar é Preciso. In: Signantia: Quasi Coelum Signância: Quase Céu. São Paulo: Ed. Perspectiva, 1979, p.11-24. BENJAMIM, W. Magia e Técnica, Arte e Política. In: Obras Escolhidas. São Paulo: Ed. Brasiliense, 1996. Vol. 1, p. 222-234.

BORGES, J.L. Kafka y sus Precursores, In: Prosa Completa. Buenos Aires: Bruguera, 1982, vol.2, p 226-228.

BRANDÃO, J. L. Primórdios do Épico: A Ilíada. In: APPEL, M. B.; GOETTEMS, M.B. (org) As Formas do Épico. Porto Alegre: Ed. Movimento/ UFRGS, 1992.

CANDIDO, A. O Direito à Literatura. In: Vários Escritos. São Paulo: Duas Cidades, 2004, p. 169-192.

CAMPOS, H. A Obra de Arte Aberta (1955) In: CAMPOS, H., CAMPOS, A. e PIGNATARI, D. Teoria da Poesia Concreta. São Paulo: Ed. Invenção, 1975, p. 30-33. . Xadrez de Estrelas. São Paulo: Ed. Perspectiva, 1976.

1979. . Signantia Quasi Coelum, Signância Quase Céu. São Paulo: Ed. Perspectiva,

. Finismundo: A Última Viagem. Ouro Preto: Tipografia do Fundo de Ouro Preto, 1990.

. Da Razão Antropofágica: diálogo e Diferença na Cultura Brasileira.

In: Metalinguagem e Outras Metas. São Paulo: Ed. Perspectiva, 1992, p.231-256. . Sobre Finismundo: a última viagem. Rio de Janeiro: [7 Letras], 1996. . Poesia e Modernidade: Da Morte do Verso à Constelação. O Poema PósUtópico. In: O Arco Íris Branco. São Paulo: Ed. Imago, 1997, p. 243-270. . Crisantempo: No Espaço Curvo Nasce Um. São Paulo: Ed. Perspectiva, 1998. . A Máquina do Mundo Repensada. São Paulo: Ateliê Editorial, 2000. . Depoimentos de Oficina. São Paulo: Unimarco, 2002. . Ora Direis, Ouvir Galáxias In: Galáxias. 4ª ed. São Paulo: Ed. 34, 2004, p. 119-123.

DIAS, G. I-Juca-Pirama. In: TEIXEIRA, I. Multiclássicos Épicos. São Paulo: Edusp/ Imprensa Oficial, 2008, p. 1131-1151.

FERREIRA, A.B. Novo Dicionário Aurélio. Rio de Janeiro: Nova Fronteira, 1999.

FRANCHETTI, P. O Triunfo do Romantismo: Indianismo e Estilização Épica em Gonçalves Dias. In: In: TEIXEIRA, I. Multiclássicos Épicos. São Paulo: Edusp/ Imprensa Oficial, 2008, p. 1097-1130.

MARGEL, S. As denominações órficas da sobrevivência: Derrida e a questão do pior. In: NASCIMENTO, E.; GLENADEL, P. Em Torno de Jacques Derrida. Rio de Janeiro: [7letras], 2000, p. 203-230.

SARDUY, S. Rumo à concretude. In: CAMPOS, H. Signancia Quasi Coelum, Signância Quase Céu. São Paulo: Perspectiva, 1979, p.117-126.

SCHÜLER, D. Um lance de nadas na épica de Haroldo. Ponta Grossa: UEPG/ Museu Arquivo da Poesia Manuscrita, 1997. Col. Mapa. 
TONETO, D. J. M. “Firma de Poesia”: o projeto poético de Haroldo de Campos

SISCAR, M. A Paixão Ingrata. In: NASCIMENTO, E.; GLENADEL, P. Em Torno de Jacques Derrida. Rio de Janeiro: [7letras], 2000, p. 160-187.

VIEIRA, T. A Odisséia de Haroldo de Campos (apresentação). In: Odisséia de Homero: fragmentos. Tradução de Haroldo de Campos. CAMPOS, I.; TÁPIA, M. (org.). São Paulo: Olavobrás, 2006, p.5,6.

TONETO, D. J. M. Convergências em A Máquina do Mundo Repensada: Poesia e Sincronia em Haroldo de Campos. Tese de doutoramento. Araraquara: UNESP/ Faculdade de Ciências e Letras, 2008. 298p. 


\title{
O erotismo em Manuel Bandeira: o limite das palavras e a revelação pelo ocultamento
}

\author{
Norberto Perkoski (Universidade de Santa Cruz do Sul - UNISC)
}

\begin{abstract}
RESUMO: Este trabalho aborda a poética erótica de Manuel Bandeira, revelando a predominância de uma escritura transgressora pelo ocultamento. A linguagem tende, por um lado, a amenizar o que dito de outra forma pareceria grosseiro e, por outro, busca atingir a ultrapassagem sígnica para melhor desvelar o êxtase da paixão e a dificuldade de expressá-la, resultando o paradoxo que une excesso e falência. Como Eros apresenta várias faces, Manuel Bandeira não foge a nenhuma delas, focalizando-as através de uma escritura que ora aparece vestida, ora cintila a sua nudez, ora esconde para melhor entrever a força deslocadora que a sensualidade impõe ao humano.
\end{abstract}

PALAVRAS-CHAVE: poesia, erotismo, escritura erótica, Manuel Bandeira.

\begin{abstract}
This paper broaches the erotic poetry of Manuel Bandeira, unveiling the prevalence of a transgressive writing through its concealment. The language tends, on the one hand, to mitigate what otherwise might sound rude, while, on the other hand, it seeks to attain the signic trespassing able to depict passion's extasy and the difficulty to express it, thus resulting in the paradox which fuses excess and failure. Given that Eros is multifaceted, Manuel Bandeira does not evade any of those faces, by portraying them through a writing both dressed and nude and sometimes hidden to better depict the dislocating strength which sensuality imposes to mankind.
\end{abstract}

KEYWORDS: poetry, eroticism, erotic writing, Manuel Bandeira.

Considerado pela crítica como a obra em que Manuel Bandeira ${ }^{1}$ atinge o seu momento de maturidade dentro da proposta modernista, que se vinha ensaiando nas obras anteriores,Libertinagem (1930) apresenta poemas eróticos que incorporam plenamente o verso livre e a liberdade de linguagem, no que tange ao aspecto formal, e a simplicidade do cotidiano, no que se refere ao plano conteudístico. Esses elementos também se farão presentes nas obras seguintes sem que, entretanto, o poeta abdique de alguns dos motivos eróticos já trabalhados nas anteriores, ou, melhor dizendo, o poeta assimila essas conquistas e incorpora-as também à temática que se associa ao amor, ao erotismo 
e à constelação que a envolve. Davi Arriguci Jr. ressalta que, em Libertinagem, Manuel Bandeira une "ostensivamente transgressão formal e erotismo" (1990, p. 163).

O poema de abertura "Não sei dançar" retoma o motivo de "Sonho de uma terça-feira gorda" deCarnaval (1919), só que agora não mais em nível onírico, e, sim, de realidade ("Eis por que vim assistir a este baile de terça-feira gorda"), uma vez que o eu-poético tenta integrar-se na folia:

Uns tomam éter, outros cocaína.

Eu já tomei tristeza, hoje tomo alegria.

Tenho todos os motivos menos um de ser triste. (p. 93)

O verso final da citação anterior, pleno de auto-ironia, será retrabalhado e explicitamente esclarecido na segunda estrofe, na qual elementos autobiográficos são usados como matéria poética:

Sim, já perdi pai, mãe, irmãos.

Perdi a saúde também.

É por isso que sinto como ninguém o ritmo do jazz-band.

A categoria de Bakhtin (1981) da livre integração entre os homens no período carnavalesco se faz presente internamente no poema, pois uma arrumadeira dança com o ex-prefeito municipal e também um japonês - "a fração incipiente amarela" - participa da festa, e o eu-lírico não deixa, de certa forma, de se enternecer com essa amálgama racial: "De fato este salão de sangues misturados parece o Brasil..."

Os elementos eróticos aparecem representados na avaliação sensual e competitiva entre duas figuras femininas:

\footnotetext{
A filha do usineiro de Campos

Olha com repugnância

Para a crioula imoral.

No entanto o que faz a indecência da outra

É dengue nos olhos maravilhosos da moça.

E aquele cair de ombros...
}

Mas ela não sabe...

Tão Brasil! (p. 93-94)

A estrofe final abre com um verso em que a intromissão racional do eu-lírico tenta, momentaneamente, solapar a pretensão de participação festiva: "Ninguém se lembra da política..." O fecho reticencial desdobra-se, no entanto, em duas direções: a percepção 
do caráter alienante do carnaval e, por outro lado, a aceitação resignada de que não só de conscientização se faz a vivência humana. Na seqüência poemática, depois de salientar a grandeza territorial do Brasil e a primazia da qualidade do algodão do Seridó, o eu-lírico abandona essas preocupações racionalistas: "Que me importa?". Inclusive as doenças (a do próprio poeta implicitamente incluída), arroladas nos versos finais, são como se fossem igualmente catapultadas da festa:

Não há malária nem moléstia de Chagas nem ancilóstomos.

A sereia sibila e o ganzá do jazz-band batuca.

Eu tomo alegria!

Em "Na boca", outro poema que focaliza o tempo transgressor do carnaval, a primeira estrofe evidencia a tristeza e a impotência existencial:

Sempre tristíssimas estas cantigas de carnaval

Paixão

Ciúme

Dor daquilo que não se pode dizer (p. 113)

Contudo, novamente se insere a compreensão da necessidade da alienação, embora o eu-lírico não consiga atingi-la e passe a projetá-la na inveja de quem se joga integralmente nela. Comprove-se:

Felizmente existe o álcool na vida

E nos três dias de carnaval éter de lança-perfume

Quem me dera ser como o rapaz desvairado!

$\mathrm{O}$ ano passado ele parava diante das mulheres bonitas

E gritava pedindo o esguicho de cloretilo:

- Na boca! Na boca!

Umas davam-lhe as costas com repugnância

Outras porém faziam-lhe a vontade.

O desvario do rapaz encontrará eco nas pretensões mais recônditas do eu-lírico, em que

o erótico se sobressai por detrás do "desejo incontentado" (ver em A cinza das horas, o poema "Tu que me deste o teu cuidado...", p. 35-36):

Ainda existem mulheres bastante puras para fazer vontade aos viciados

Dorinha meu amor...

Se ela fosse bastante pura eu iria agora gritar-lhe como o [outro:

- Na boca! Na boca! 
Predominantemente, o erotismo corporal em Manuel Bandeira, em função da tuberculose como componente impeditivo, evade-se ou para o imaginário, de que "Voume embora pra Pasárgada" (p. 117-118) é um exemplo significativo, tanto que nesse espaço utópico o poeta terá as mulheres que quiser, ou busca na infância os seus correlatos de espanto, encantamento e ternura. Para esse segundo caso, comprove-se com os seguintes excertos de "Evocação do Recife":

Um dia eu vi uma moça nuinha no banho

Fiquei parado o coração batendo

Ela se riu

Foi o meu primeiro alumbramento

$[\cdots]$

Eu me deitei no colo da menina e ela começou a passar a

[mão nos meus cabelos (p. 106)

O encantamento infantil, enquanto evasão erótica, é tema também de "Porquinho-daíndia" (p. 100), no qual o eu-lírico afirma que o bichinho foi a sua primeira namorada. É importante elucidar que esse poema faz parte de um tríptico intratextual, sendo "Teresa" e "Madrigal tão engraçadinho" os outros dois. $\stackrel{2}{2}$

O segundo dos poemas da tríade ("Teresa") interessa de modo particular, porquanto trabalha poeticamente a noção de o ser perder-se de maneira completa quando envolvido pelo erótico.

Um outro dado que se torna interessante salientar é o fato de o poema também fazer uso da intertextualidade, estabelecendo um canto paralelo com "O 'adeus' de Teresa", criação lírica de Castro Alves, utilizando-se, de certa forma, da técnica composicional do poeta baiano, no entanto, alterando-lhe o processo seqüencial.

No poema de Castro Alves, o envolvimento do par amoroso ocorre através de três fases que se poderiam denominar de encontro comprometido, relação sexual, separação problemática. Em Manuel Bandeira o processo é diverso: negação do corpo, negação da alma através do corpo e relação sexual. Veja-se o poema deste último:

\section{TERESA}

A primeira vez que vi Teresa

Achei que ela tinha pernas estúpidas 
Achei também que a cara parecia uma perna

Quando vi Teresa de novo

Achei que os olhos eram muito mais velhos que o resto do corpo (Os olhos nasceram e ficaram dez anos esperando que o resto do [corpo nascesse)

Da terceira vez não vi mais nada Os céus se misturaram com a terra E o espírito de Deus voltou a se mover sobre a face das águas. (p. 107-108)

Muitas vezes, o deslocamento que o desejo provoca, quando ainda inconsciente, é o da negação do objeto. Pelo temor de sucumbir ao que lhe é estranho em termos de racionalidade, ao que o ultrapassa conscientemente, o ser, num revés defensivo, procura destruir as qualidades daquilo que o atrai intensamente. É o que acontece no poema em pauta.

As duas primeiras estrofes exibem a negação do corpo do Outro, com uma diferença entre elas. Na primeira, o que é negado são as "pernas estúpidas". Note-se a escolha do adjetivo, que indica uma qualidade de caráter abstrato, atribuído à concretude de uma parte corporal à qual costumeiramente não vem associado. $\mathrm{O}$ temor, como se fosse um ato falho, trai o eu-lírico pelo deslocamento do termo, revelando, por um duplo viés, agressividade e ignorância. Quando, no último verso, o eu-lírico associa a cara à perna, transfere a sua avaliação e expõe, de forma mais evidente ainda, o seu receio.

A negação temerosa atinge o seu ápice na segunda estrofe através da consideração do olhar. A sabedoria popular, valendo-se do desgastado provérbio de que "os olhos são o espelho da alma", patenteia, aqui, uma verdade. O tom sarcástico, desmerecedor, do eulírico em relação ao Outro, é destruído pela "velhice" dos olhos, conotadora que é, no poema, de vivência antecipada, sabedoria, compreensão.

$\mathrm{Na}$ terceira estrofe, o eu-lírico sucumbe integralmente ao olhar do Outro, ambos fundindo-se em uma unidade, tornada evidente através do verbo reflexivo recíproco "se misturaram", que envolve tanto o sujeito quanto o objeto, sem distingui-los ou separálos.

"Madrigal tão engraçadinho", o terceiro poema da série, complementa o enleio encantatório pela figura feminina. O eu-lírico retoma do mundo mágico e feliz da 
infância a imagem do seu primeiro fascínio. A estranheza inicial da comparação (cf. também o poema "Namorados", p. 116) transmuta-se num galanteio sedutor, quando se tem em mente os outros dois poemas da tríade:

\section{MADRIGAL TÃO ENGRAÇADINHO}

Teresa, você é a coisa mais bonita que eu vi até hoje na minha vida, inclusive o porquinho-da-índia que me deram quando em tinha seis anos. (p. 112)

O clima surreal e a entrega plena que encerra o poema "Teresa" também se faz presente no poema inaugural e homônimo da obra Estrela da manhã (1936), no qual o eu-lírico num tom exacerbado no todo da composição e iniciando pela manifestação do desejo e da perda do objeto desejado ("Eu quero a estrela da manhã"; "Ela desapareceu ia nua") manifesta a sua intenção de comprometimento, mesmo que "a estrela da manhã" tenha se relacionado com vários tipos de homens:

Virgem mal-sexuada Atribuladora dos aflitos Girafa de duas cabeças

Pecai por todos pecai com todos

Pecai com os malandros Pecai com os sargentos Pecai com os fuzileiros navais Pecai de todas as maneiras Com os gregos e os troianos Com o padre e com o sacristão Com o leproso de Pouso Alto

Depois comigo (p. 120)

Partindo-se da interpretação de que a "estrela da manhã" é a transfiguração da mulher, de certa forma idealizada pela própria abjeção, o eu-lírico propõe-se a aceitá-la integralmente, numa doação ilimitada:

Procurem por toda parte

Pura ou degradada até a última baixeza

Eu quero a estrela da manhã. (p. 121)

Cabe notar a ausência de pontuação - exceção feita às interrogações e ao ponto final do todo do poema -, expondo a intensidade do envolvimento do eu-lírico. Esse sentimento deslocador, em que, como já se viu, não estão ausentes as manifestações de erotismo 
intenso, encontra o seu correlato também na torrencialidade com que se apresenta o enunciado, abolindo as suas pausas. $\underline{3}$

Igualmente em "Balada das três mulheres do sabonete Araxá" (p. 122), o tom enfático é o mesmo, no entanto o objetivo diverge, insinuando uma situação cômica de envolvimento erotizado com as mulheres constantes em um invólucro de um produto de higiene..$^{4}$

Já em Lira dos cinqüent'anos (1940) Manuel Bandeira elabora, no poema "Água-forte", uma obra-prima no que tange à escritura erótica transgressora pelo ocultamento. Em $O$ preto no branco(1955), Ledo Ivo, através da elucidação das metáforas que compõem o poema, desnuda o caráter de um assunto interdito, trabalhado poeticamente. A linguagem oculta é desvelada por meio de uma exegese crítica que, ao cabo, revela que o poema aborda "um sexo feminino em funcionamento menstrual". ${ }^{-}$Veja-se o poema:

ÁGUA-FORTE

O preto no branco,

O pente na pele:

Pássaro espalmado

No céu quase branco.

Em meio do pente,

A concha bivalve

Num mar de escarlata.

Concha, rosa ou tâmara?

No escuro recesso,

As fontes da vida

A sangrar inúteis

Por duas feridas.

Tudo bem oculto

Sob as aparências

Da água-forte simples:

De face, de flanco,

O preto no branco. (p. 147-148)

$\mathrm{Na}$ "tradução" das metáforas, o exegeta correlaciona "pente" ao púbis; "concha bivalve", aos pequenos lábios genitais; "o mar de escarlata", ao fluxo menstrual; "as fontes da vida", aos ovários. ${ }^{6}$ Salienta, avaliativamente, o crítico: 
Focalizou o poeta um desses assuntos proibidos, sobre os quais a criação artística costuma silenciar, por pudor, conveniência e talvez por um sentimento de repulsa, calando a evidência de um espetáculo que a alguns poderia parecer uma das misérias ou maldições da condição feminina, embora seja, simplesmente, uma exibição da sabedoria da natureza. (IVO, 1955, p. 52)

Acrescenta, ainda, que Manuel Bandeira "ousou atravessar a fronteira do silêncio estabelecido em torno de uma fronteira biológica" para celebrá-la através de um "idioma cifrado, de um código lírico em que a verdade se escondesse para melhor evidenciar-se" (IVO, 1955, p. 52).

Em "Unidade", por exemplo, poema constante da obra Belo belo (1948), Bandeira valese de elementos sacros para velar a intensidade do erotismo corporal, numa síntese dialética, como se verá na análise que segue:

\section{UNIDADE}

Minh'alma estava naquele instante

Fora de mim longe muito longe

\section{Chegaste}

E desde logo foi verão

$\mathrm{O}$ verão com as suas palmas os seus mormaços os seus [entos de sôfrega mocidade

Debalde os teus afagos insinuavam quebranto e molície

O instinto de penetração já despertado

Era como uma seta de fogo

Foi então que minh'alma veio vindo

Veio vindo de muito longe

Veio vindo

Para de súbito entrar-me violenta e sacudir-me todo

No momento fugaz da unidade. (p. 184-185)

O efeito de estranhamento desse poema advém de que a civilização cristã ocidental busca atingir a transcendência pela negação do corpóreo. Através do amortecimento dos sentidos, o objetivo projetado é a anulação das sensações, entre elas, primordialmente, as vinculadas à sexualidade, com a finalidade de alcançar, através de uma revelação epifânica, a integração com o sagrado. 
Manuel Bandeira subverte o processo. Não nega o corpo, mas parte dele para alcançar a transcendência através da relação sexual. A oposição entre continuidade $\mathrm{x}$ descontinuidade, categorias caras a Georges Bataille, em sua obra O erotismo, de 1957, desdobra-se, aqui, em dois níveis: na relação do ser consigo mesmo, isto é, na separação alma/corpo; e na ligação do ser com o diferente, uma vez que o Outro é sempre o dessemelhante. A unidade - na expressão sinônima de Bataille, "a continuidade perdida" - é passível de ser reencontrada na síntese dialética que incorpora o elemento sacro corpo e alma unificam-se - quando da integração com o Outro, através do perder-se no instante do gozo. Nada assegura, contudo, o conhecimento, nem do ser, uma vez que a consciência some nesse momento de plena intensidade, nem do Outro, pois nada garante que o Outro tenha auferido a mesma plenitude.

Reitera-se que, através da escritura erótica, Manuel Bandeira, como já foi salientado por Ledo Ivo, esconde para melhor desvelar. Os elementos de seleção formal aumentam, no texto em pauta, a densidade poemática. No dístico inicial, as vogais abertas iniciais ("alalma"; "fora") parecem diluir-se nas nasalizações finais ("instante"; "longe"), distendendo os versos e alcançando, com esse recurso, o reforço do distanciamento alma $\mathrm{x}$ corpo.

$\mathrm{Na}$ segunda estrofe, com o aparecimento do Outro, deflagrador do desejo do eu-lírico, esse passa também a situar-se no tempo do desejo e da paixão imperiosa. A escolha da estação - "verão" - associa-se, pelos vocábulos eleitos como conexos ao seu campo semântico ("mormaços", "ventos de sôfrega mocidade"), à exacerbação do lado impulsivo do ser humano e, no caso específico do poema, envolve o instintivo masculino. Em contraponto tem-se a insinuação, a ondulação do Outro, pretendendo a distensão temporal, apropriadamente representada pelas nasalizações em "insinuavam" (também pelo hiato entre o "u" e o "a") e "quebranto" e pela ditongação final de "molície", que alongam o final do verso. No entanto, o tempo vencedor é o do eu-lírico e não o do Outro. A virilidade masculina suplanta a tentativa outra de prolongamento das sensações táteis. No início do verso seguinte, as vogais nasais sugerem o gradual enrijecimento do membro masculino ("o instinto de penetração") a que o eu-lírico não poderá fugir e que é reforçado pelas tônicas abertas finais ("já despertado"). A reação 
masculina aos carinhos encontra, na comparação de "seta de fogo" para o membro duro, ereto, uma resposta física imediata para a urgência da posse.

A aliteração em "veio vindo", repetida com propriedade três vezes, nos três primeiros versos da estrofe seguinte, acrescida novamente das nasalizações da própria palavra "vindo" e também de "longe", sugerem um aproximar-se gradativo e representam igualmente, na leitura proposta aqui, os movimentos masculinos da cadência rítmica de entrada e retirada do membro, do vaivém do coito. Os dois últimos versos indicam a ejaculação no nível físico e o momento final da síntese dialética unificadora do corpo e da alma, nesse instante integrados plenamente. A eleição da palavra "sacudir-me" reforça, através do significante a idéia veiculada pelo significado: a sibilante inicial, acrescida da estridência do "i" e do tremulante "r" podem ser associadas à intensidade do orgasmo masculino. O pronome "me" que se incorpora aos dois verbos ("entrar-me" e "sacudir-me") aponta para a invasão que sofre o sujeito no momento da plenitude do gozo.

No último verso, o adjetivo "fugaz" diz da impossibilidade de continuidade desse instante que é, por natureza, efêmero. O ser é, em si e para si, descontínuo. Esse "em si" deve ser entendido associando-o à dicotomia alma x corpo e o "para si" como a impossibilidade de integrar-se indefinidamente com o Outro.

O poema trabalha uma visão masculina da urgência do desejo e a figura do Outro surge, explicitamente, apenas para sugerir a extensão do tempo do desejo que - torna-se evidente pelo conteúdo poemático - não é atendido.

O próximo poema, estrategicamente colocado a seguir na disposição interna da obra, vincula-se com o precedente. Constate-se:

\section{ARTE DE AMAR}

Se queres sentir a felicidade de amar, esquece a tua alma.

A alma é que estraga o amor.

Só em Deus ela pode encontrar satisfação.

Não noutra alma.

Só em Deus - ou fora do mundo.

As almas são incomunicáveis. 
Deixa o teu corpo entender-se com outro corpo.

Porque os corpos se entendem, mas as almas não. (p. 185)

Só em momentos muito raros o ser consegue, momentaneamente, integrar-se com aquilo que o transcende e, mesmo assim, esse instante esvai-se tão logo a racionalidade invade o processo de pensamento. Daí por que em "Unidade" Manuel Bandeira faz uso da palavra "fugaz". Acrescido da vivência da impossibilidade da continuidade de fusão com o que o ultraprassa, em "Arte de amar" o poeta opta pela via do corpo, negando igualmente a integração continuada entre dois seres distintos no que tange à transcendência.

A vivência do inefável é intraduzível para o código da linguagem comum, cotidiana, pois essa centra-se na função referencial. Na tentativa de comunicar, aqueles que passam por tal experiência inventam uma linguagem outra que, ao final, se torna hermética, pois não encontra signos apropriados no código estabelecido. Além disso, essa experiência não se processa quando o ser almeja e sim em momentos singulares.

Como é impossível de comunicar o "momento fugaz" de que trata o poema "Unidade", uma vez que ele está associado à alma, ao mistério, resta, assim, tão-somente o corpo que, como trabalha Manuel Bandeira em "Arte de amar", pode chegar a um instante de participação no mistério, embora o mistério continue incognoscível.

Em alguns momentos, a linguagem de Manuel Bandeira tangencia a escritura transgressora pelo excesso, como, por exemplo, no poema "Infância", que fecha a obra Belo belo, no qual, relembrando as suas mais remotas experiências existenciais, não omite a que se refere à descoberta deslocadora do erotismo:

Uma noite a menina me tirou da roda de coelho-sai, me [levou, imperiosa e ofegante, para um desvão [da casa de Dona Aninha Viegas, levantou a [ sainha e disse mete. (p. 189)

Yudith Rosenbaum assim se refere a essa passagem: 
No poema "Infância", a atitude decidida da menina ressalta em meio à passividade assustada do garoto. Todos os verbos referem-se a ela, cabendo a ele apenas cumprir a ordem imperativa: "mete". A carga maior concentra-se toda neste verbo, cujo tom ordenativo finaliza o verso, deixando ausente do poema a cena explícita. (1993, p. 68)

Resta salientar que, se no conjunto de sua obra, Manuel Bandeira elabora, predominantemente, uma escritura erótica insinuadora, em determinados poemas ocorre a tensão entre o erotismo evidenciado e o erotismo oculto, pois uma vez desvelado o que se esconde, expõem-se tanto a temática do interdito quanto a intensidade das imagens eleitas. Veja-se, como exemplo do que foi por último afirmado, o poema que segue, constante de Opus 10 (1950), em que se elege como intertexto um livro bíblico:

\section{CÂNTICO DOS CÂNTICOS}

- Quem me busca a esta hora tardia?

- Alguém que treme de desejo.

- Sou teu vale, zéfiro, e aguardo

Teu hálito... A noite é tão fria!

- Meu hálito não, meu bafejo,

Meu calor, meu túrgido dardo.

- Quando por mais assegurada

Contra os golpes de Amor me tinha,

Eis que irrompes por mim deiscente...

- Cântico! Púrpura! Alvorada!

- Eis que me entras profundamente

Como um deus em sua morada!

- Como a espada em sua bainha. (p. 203-204)

Subvertendo o texto original que se manifesta pleno da ternura e do cuidado de Salomão para com a rainha de Sabá, o eu-lírico do poema em foco manifesta a sua urgência através de uma linguagem agressiva. Frente ao enunciado feminino que busca imagens brandas e evanescentes para o seu desejo, contrapõem-se as falas masculinas que, uma vez decodificadas e associadas ao todo poemático, se revelam como transgressoras pelo excesso, marcadas que são pela intensidade ("Alguém que treme de desejo") e representadas pela ostensividade tanto de "bafejo", que se pode considerar como uma palavra agressiva, quanto de símbolos fálicos hostis, tais como "túrgido dardo" e "espada". 
Por fim, é pertinente reiterar que, na poética erótica de Manuel Bandeira, a linguagem tende, por um lado, a amenizar o que dito de outra forma poderia parecer grosseiro e, por outro, busca atingir a ultrapassagem dos signos lingüísticos para melhor revelar o êxtase da paixão e do gozo e a dificuldade de expressá-los em palavras, resultando, dessa forma, o paradoxo de uma linguagem que une excesso e falência.

Este estudo analítico ressalta, ao seu término, a invasão criativa que o poeta faz da temática do proibido. Na eleição dos temas e na intensidade com que são tratados, evidenciam-se formas de transgredir o interdito: uma que se oculta para melhor revelar, como em "Água-forte"; outra que tensiona a escritura em suavidade e agressividade, como em "Cântico dos cânticos".

Como Eros não se deixa aprisionar e apresenta inúmeras faces que vão desde o olhar extasiado, passando pela carícia amena até o desejo premente e agressivo, Manuel Bandeira não foge a nenhum desses disfarces, focalizando-os através de uma escritura que ora aparece vestida, ora cintila a sua nudez, ora esconde para melhor revelar a força deslocadora que a sensualidade impõe ao humano.

\section{NOTAS}

${ }^{1}$ Todas as citações do poeta serão extraídas da obra Estrela da vida inteira: poesias reunidas, 8. ed., Rio de Janeiro: J. Olympio, 1980, podendo ser confrontadas através das páginas colocadas entre parênteses no decorrer do trabalho. Cumpre esclarecer que este texto teve por base um dos capítulos de nossa tese de doutorado "A escritura erótica no sistema literário brasileiro", defendida em 1996, na PUCRS.

${ }^{2} \mathrm{Na}$ Revista do GT de Teoria do Texto Poético no 4, de 2007, no artigo "Fragmentos de uma subjetividade poética: três poemas de amor de Libertinagem, de Manuel Bandeira, Wilson José Flores Jr. também focaliza os textos em pauta. Disponível em: http://www.textopoetico.org

${ }^{3}$ Franklin de Oliveira apresenta uma interpretação semelhante:

Uma das características formais do poema é a ausência quase completa de pontuação. O apelo a esse recurso não obedece apenas a uma necessidade rítmica: é uma imposição de ordem psicológica. Eliminando a virgulação no verso patético, o poeta torna ainda mais impraticável a discriminação entre amigos e inimigos. A todos transmite um apelo patético: o de sua angústia. 
Cf. OLIVEIRA, Franklin de. O medievalismo de Bandeira: a eterna elegia. In: BRAYNER, Sônia (Org.). Manuel Bandeira. Rio de Janeiro: Civilização Brasileira; Brasília: Instituto Nacional do Livro, 1980. p. 256.

${ }^{4}$ Partindo de algumas pistas fornecidas pelo próprio poeta, Sônia Brayner realiza a análise desse poema, apontando os elementos intertextuais nele existentes. Cf. "O 'humour' bandeiriano ou as histórias de um sabonete". In: LOPEZ, Telê Porto Ancona. (Org.). Manuel Bandeira: verso e reverso. São Paulo: T. A. Queiroz, 1987. p. 42-47.

${ }^{5}$ IVO, Ledo. O preto no branco: exegese de um poema de Manuel Bandeira. Rio de Janeiro: São José, 1955. p. 47. Salienta-se que o poema em pauta já recebeu interpretação distinta da que se verá no corpo do texto. Para Leônidas Câmara, o poema focaliza "o misticismo do poeta [...] embora esbatido numa figuração de repetidas imagens plásticas interiorizadas". Acrescenta, ainda, o crítico:

em "Água-forte" tudo se reduz, afinal, à situação de início esboçada. A disposição dos objetos, sua escala cromática, o preto, o branco, o mar de escarlate, o céu quase todo branco, enfim, água-forte simples, todo esse jogo de contrastes, de imagens alternadas, duas a duas, contribui para formar o quadro sugerido mais pelas concepções abstratas do poeta que pela plana sensibilidade.

Cf. o artigo "A poesia de Manuel Bandeira: seu revestimento ideológico e formal". In: BRAYNER, Sônia (Org.). Manuel Bandeira. Rio de Janeiro: Civilização Brasileira; Brasília: Instituto Nacional do Livro, 1980. p. 173.

${ }^{6} \mathrm{Cf}$. a obra de Ledo Ivo, referenciada na nota 5, respectivamente as páginas 39, 49, 50 e 51.

\section{OBRAS CITADAS}

ARRIGUCCI JR., Davi. Humildade, paixão e morte: a poesia de Manuel Bandeira. São Paulo: Companhia das Letras, 1990.

BAKHTIN, Mikhail. Problemas da poética de Dostoiévski. Tradução de Paulo Bezerra. Rio de Janeiro: Forense-Universitária, 1981.

BANDEIRA, Manuel. Estrela da vida inteira: poesias reunidas. 8. ed. Rio de Janeiro: J. Olympio, 1980.

BATAILLE, Georges. O erotismo. Tradução de Antonio Carlos Viana. Porto Alegre: L\&PM, 1987.

BRAYNER, Sônia. O 'humour' bandeiriano ou as histórias de um sabonete. In: LOPEZ, Telê Porto Ancona. (Org.). Manuel Bandeira: verso e reverso. São Paulo: T. A. Queiroz, 1987. 
CÂMARA, Leônidas. A poesia de Manuel Bandeira: seu revestimento ideológico e formal. In: BRAYNER, Sônia (Org.). Manuel Bandeira. Rio de Janeiro: Civilização Brasileira; Brasília: Instituto Nacional do Livro, 1980.

FLORES JR., Wilson José. Fragmentos de uma subjetividade poética: três poemas de amor de Libertinagem, de Manuel Bandeira. Revista do GT de Teoria do Texto Poético, v. 4, 2007. Disponível em: http://www.textopoetico.org

IVO, Ledo. O preto no branco: exegese de um poema de Manuel Bandeira. Rio de Janeiro: São José, 1955.

OLIVEIRA, Franklin de. O medievalismo de Bandeira: a eterna elegia. In: BRAYNER, Sônia (Org.).Manuel Bandeira. Rio de Janeiro: Civilização Brasileira; Brasília: Instituto Nacional do Livro, 1980.

PERKOSKI, Norberto. A escritura erótica no sistema literário brasileiro. 1996. $312 \mathrm{f}$. Tese (Programa de Pós-Graduação em Letras) - Pontifícia Universidade Católica do Rio Grande do Sul, Porto Alegre, 1996.

ROSENBAUM, Yudith. Manuel Bandeira: uma poética da ausência. São Paulo: Universidade de São Paulo; Rio de Janeiro: Imago, 1993. 


\title{
Entre Jacob e Narciso, o desespero e a redenção na poética de Murilo Mendes
}

\author{
Maria Marta dos Santos Silva Nóbrega (UFCG)
}

RESUMO: A partir de poemas de As metamorfoses e A poesia em pânico, o trabalho analisa como a poética de Murilo Mendes atualiza os mitos de Jacob e Narciso quando busca resgatar sua auto-imagem. Os mitos ressurgem como forma de desmascarar e recriar as bases da criação poética muriliana. O trabalho noturno de Jacob em seu combate árduo com Deus até receber o emblema da libertação através do novo nome é revitalizado pelo poeta ao travar uma luta com a palavra buscando-lhe a plenitude do sentido. Na atualização do mito de Narciso, tem-se um ser poético debatendo-se nas tensões simbólicas do texto em procura de imagens de si e do mundo. Assim, mito e modernidade se articulam para que a poesia dê conta da autoconsciência desesperada do autor que busca incessantemente restaurar e redimir a poesia.

PALAVRAS-CHAVE: Murilo Mendes, Mito, Jacob, Narciso.

\begin{abstract}
Based on poems in As Metamorfoses e A poesia em pânico, the work analyses the poetics in Murilo Mendes brings up to date the myths of Jacob and Narcissus as the seeks to rescue his self-portrait. Jacobs's night struggle during his hard fight with God, until he receives the liberation emblem through the new name, is revived by the poet as he engages in a battle with the word, searching for the fullness of sense. In bringing up to date the myth of Narcissus, there is the poetic being struggling with the symbolic tensions of the text, as he searches for the images of himself and the world. Thus, myth and modernity are joined so that poetry accounts for the desperate self-consciousness inside the author, who incessantly seeks to restore and redeem poetry.
\end{abstract}

KEYWORDS: Murilo Mendes, myth, Jacob, Narcissus. 
Abordar a obra de Murilo Mendes como uma poética do desespero e da redenção exige bastante esforço posto que o sentido de cada um dos termos não é perceptível de forma translúcida. $\mathrm{O}$ vocábulo desespero provém de dis-sperare e engloba a idéia de não confiar, perder as esperanças. Pode, portanto, ser entendido como tudo o que desconcerta, desune, separa e se opõe.

A nossa primeira hipótese é que o desespero enquanto estruturador da poética de Murilo Mendes coloca-se imaginariamente como uma necessidade que impulsiona o poeta a indagar pela sua identidade histórica e a vivenciar, a partir do eu, o drama de sua experiência vital. Necessidade plasmada na afirmação de brasilidade e universalidade pretendida pelos modernistas brasileiros. Nessa perspectiva, o imaginário poético do autor desenvolve-se em torno de uma expressão lírica que intenta buscar, no caos, a essência e a ordem ocultas na realidade circundante.

Já o vocábulo redenção, etimologicamente, vem do latim redimere e significa adquirir de novo, tirar do poder alheio. Um novo sentido que se pode extrair do termo é o de reunião de realidades opostas de tal forma que elas permaneçam juntas. Assim, em Murilo, a partir do desconserto provocado pelo desespero, o poeta assume a posição demiurgo de redentor, de criador e organizador de todo um Universo.

A idéia de mundo como desespero é responsável pela fragmentação do real e Murilo Mendes explora até a exaustão esta temática. Ao intercalar a consciência entre o eu e o mundo, o autor passa a ver as coisas como imagens descontínuas que a mente tenta desesperadamente harmonizar num todo coerente. A partir desta ausência de esperança, o poeta encontra, na tristeza, a força de sua poética. Poética de dissonância, pois a partir das causas do desespero, o eu constrói a redenção da poesia, posto que não há mais "tentação".

Em Murilo, os mitos de Jacob e Narciso ressurgem como forma de refletir e refratar, de desmascarar e recriar as bases estruturais da criação poética. Assim, a criação tende a ser reafirmada através do impulso do poeta ao vitalizar a poesia. $\mathrm{O}$ trabalho noturno de Jacob em seu combate árduo com Deus até receber, ao raiar do dia, o emblema da libertação através do novo nome é revitalizado pelo poeta que trava uma luta com a palavra buscando-lhe a plenitude do sentido. 
Tal como acontece com Jacob, o homem moderno está sempre sob o ataque e uma ameaça de morte que vem do exterior, ao mesmo tempo que, em seu interior, experimenta um enfrentamento não menos estafante entre o instinto de morte e a aspiração à vida, entre o espírito de mentira e o espírito de verdade; para reintegrar o espírito, é preciso passar pelas provas de uma iniciação, ao termo da qual o homem poderá 'pôr-se de pé', receberá um novo nome, como Jacó que renasceu chamando-se Israel (COUFFIGNALL, In. BRUNEL: 1977, p. 515-51)

O arquétipo de Jacob, herói consciente e duelador, trabalhando incessantemente pelo seu ideal, que nos interessa aproximar dos empenhos e impasses de alguma poesia de Murilo, que por sua vez inscreve-se na práxis da lírica moderna, a poesia da consciência vigilante, crítica e auto-reflexiva.

Agora, outra questão se põe: que tem a ver a poesia lírica moderna e mais precisamente a de Murilo Mendes com este mito de Jacob? Diríamos, desde já, que a forma arquetípica desse mito de resistência apresenta-se como um dos substratos simbólicos que justificam o acontecer poético nos conturbados tempos modernos, moldando a sensibilidade e a dramaticidade da auto-referência poética diante da obliteração enquanto totalidade significativa.

Ao voltar-se para si, buscando a sua face, a poesia moderna também busca reconstruir uma imagem do mundo, ou melhor, ela reflete e ao mesmo tempo refrata os impasses fundamentais do homem. Ao lutar com a palavra, antes que chegue a aurora da revelação poética, o poeta adquire consciência do seu ato diante do mundo. Ato que é uma forma de resistência e transcendência; uma busca que é também destino, ponto de chegada, ponto de encontro e reencontros.

Nesse contexto, o poema manifesta-se como um lugar privilegiado, fecundo de faces e falas diversas, pois a ponte da leitura que conduz ao mundo do fazer e do existir humanos, o mundo da história, é a mesma que conduz esse mundo de volta ao seu interior, ou seja, ao interior do poema. Fecha-se, assim, um círculo estranho no qual a linguagem, que deveria traduzir o universo humano, encena diante de si a própria existência. Homem e poesia se fundem, se confundem na metapoesia moderna, como 
Jacob tornou-se uma fusão de Esaú e Jacob na busca de um sentido - Israel, o poeta moderno, busca construir um significado para a vida.

Assim, poderíamos dizer que a poesia lírica, sob esse signo do eterno retorno do mesmo, reflete o drama de Jacob, ou seja, a ascensão e queda da linguagem humana, atuando nos limites da representação do mundo e da auto-referência (fala e afasia), buscando uma imagem de mundo nos abismos de suas imagens e miragens.

Há na lírica moderna, uma linguagem, como o próprio homem, compelida a se reelaborar a se renomear, a confrontar seus valores em ritmo e lutas alucinantes. Uma linguagem pejada de símbolos e espantos, de buscas e vazios, que "tanto desce como sobe...", como se pode ver em "Novíssimo Jacob":

\section{NOVÍSSIMO JACOB}

Antes de eu nascer tu velavas sobre mim

E mandaste teu anjo substituir minha mãe morta

Ele me continha quando eu corria à beira mar

Ou quando me debruçava sobre o abismo,

Cantava serestas e acalantos

Para aplacar minhas horas de pedra.

Às vezes uma vasta sombra atravessa os dias:

E de noite eu ouvia claramente os passos do serafim

Perderem-se nas estrelas do céu.

Mais tarde uma mulher ao meu lado

Tinha um esboço de asas nas espáduas

E na minha alma diminuíam os cuidados do tempo.

Manda-me de novo teu anjo

A fim de lavar as minhas chagas,

A fim de refrescar a minha boca:

Há dias em que nem mesmo tua palavra nos sustém.

É preciso que eu te veja nos menores detalhes,

É preciso que eu seja não só eu, também tu.

E que encare o sofrimento como um céu aberto,

E tua luz descendo e subindo sobre mim.

(Tempo e Eternidade, PCP.,p., 251)

A própria divisão do poema em dois momentos já sugere o desterro existencial do poeta e sua desarticulação representativa. Neste poema, o vazio inicial - ausência do místico - que ronda o texto constitui o drama existencial que envolve o eu lírico. A substancialidade desse vazio é flagrante nos tempos verbais da primeira estrofe, todos no pretérito: "velavas", "mandaste", "continha", "corria", "debruçava", "cantava", "atravessava", “ouvia”, "perderem-se”, “tinha”, “diminuíam”. Tal recurso estilístico 
reforça um drama corpóreo-existencial que o poeta persegue através da face textual: uma imagem de mundo escorregadia que faz voltas em si, mas ao mesmo tempo projeta a consciência ativa que busca a transcendência no interior da própria crise existencial.

A figura mística - o anjo e depois a mulher - transformou a angústia do poeta órfão em um concerto com "serenatas e acalantos", reforçando assim o caráter transcendental da linguagem poética elaborada em "dias que nem mesmo tua palavra (do místico) nos sustém". O esvaziamento da vida alvitra o esvaziamento do discurso poético. Bloqueadas, a vida e a linguagem poética, o poeta faz o concerto com os despojos que lhe restaram - as chagas -, ou seja, a opção de viver e de fazer poemas, desejando voltar a ver o místico "nos mínimos detalhes". Não fosse essa opção consciente pelo reaparecimento do anjo, a sede pelo mistério e pela mística, o poema estaria para sempre perdido no sem-sentido, na impertinência do discurso frente às "horas de pedra".

A emergência dramática que impulsiona o desejo de "encarar o sofrimento como um céu aberto", sugere que a poesia lírica moderna foi condenada a ter como totalidade em seu horizonte expressivo apenas o fragmentário que marca o seu corpo. O poema "Novíssimo Jacob" dramatiza esse antagonismo, pois sabe o poeta, em seu exercício textual, que as linhas entre o efêmero e o eterno, a parte e o todo, são tênues. Onde se situar nesse trajeto? Nas angústias da existência em chagas e sede, ou na "luz descendo e subindo" sobre o poeta? Para responder a essas perguntas, o poeta, em "Novíssimo Jacob", apresenta-se como o ser que busca no espaço metalinguístico a sua realização e revelação poética.

Tal qual Jacob encontrou razões para sua existência na luta com o anjo, assim procede o poeta ao vislumbrar a "luz descendo e subindo" sobre si. A dualidade expressa pela imagem verbal "descendo e subindo" sugere a complexidade do processo literário, em que o criador parte de uma atmosfera caótica, porém extremamente fértil e dá ordem ao seu universo poético.

No poema "O poeta futuro", o eu lírico confessa-se "o homem sereno, a síntese de todas as raças, o portador da vida" que "saiu de tanta luta e negação e do sangue espremido" para construir o sentido que justifique a vida. Não só justifique, mas o faça 
prosseguir, sempre em transformação, ainda que este caminho seja árduo e o instigue a transformar "o aço de sua espada/ em penas que escreverão poemas consoladores".

Outra aproximação do poeta com o arquétipo de Jacob, pode ser vista no poema "O Pastor pianista". O texto, imbuído de forte imagística surrealista, apresenta a figura do poeta-pastor como um novíssimo Jacob apascentando pianos que, por sua poesia, leva à divindade o "antigo clamor do homem.

Ao analisar este poema, Antonio Candido enfatiza que o texto provoca um efeito de surpresa ante o inesperado: ao propor uma poesia pastoril, são seres inanimados pianos - que o poeta apascenta. De acordo com o crítico, este efeito sugere uma "poética da ausência", em que as palavras inesperadas preenchem os vazios deixados pelo que, eventualmente, o leitor esperaria.

Em “A Criação e o Criador" - poema que abre o "Livro Segundo" de As Metamorfoses - o poeta se faz novo Jacob, lutador, capaz de despertar, com sua magia verbal, a noite, o sono do poema obscuro, dando-lhe "essência, corpo," vida.

Considerando que o ato criador é um processo, sua primeira dimensão implica na imprevisibilidade. O poema tem o tom de uma profissão de fé marcada pela aventura de quem mesmo, tendo se preparado cuidadosamente para uma jornada poética a fim de dar essência ao poema, não sabe, o poeta, o caminho no qual é lançado, posto que, vê-se perseguido pelo próprio poema. O poema, antes dependente do poeta, agora apresentase autônomo, personificado, incomoda o poeta e deve voltar "ao pó de onde proveio". Tal como Jacob combate com seu criador e busca uma autonomia, o discurso metalinguístico de "A criação e o Criador" sugere a luta do poeta com as palavras, ao ponto de desejar adormecer o poema e vê-lo reduzido à sua essência primeira: o pó.

Já com relação ao arquétipo de Narciso, veremos que Murilo atualiza a força expressiva do mito ao buscar sua auto-imagem, a consciência do ser poético - latente e manifesto - no espelho da linguagem textual. No confronto do poeta com o arquétipo de Narciso delineia-se o problema da crescente perda de identidade e integridade que subjaz aos padrões individuais da vida moderna. 
A construção da imagem poética (o pathos), em alguns textos murilianos, represa as águas que banham ou refletem o arquétipo do belo Narciso. Ao cruzar o mito de Narciso com a poesia de Murilo Mendes, sobressai, com grande vitalidade simbólica, uma das faces cruciais da poesia moderna, a consciência metalinguística inerente ao ato criador. Uma metalinguagem que é fruto, sobretudo, da crise de valores do mundo moderno que afetou o próprio caráter representativo da linguagem. Ou seja, busca da identidade expressiva como forma de resistência aos padrões existenciais da modernidade.

O arquétipo mítico de Narciso, ressurge não apenas como símbolo de contemplação e fruição do seu próprio ser, mas sobretudo como signo que busca a verdadeira identidade, o pleno (re)conhecimento de si. Dessa forma, a poesia de Murilo Mendes caracteriza-se tanto pela busca do reflexo do eu, das imagens do ser e do mundo codificados no texto, como também pelo desvelamento do eu do reflexo, ou seja, o ser do poema (linguagem e forma) a mirar-se na própria mirada do poeta. Vejamos "Poema visto por fora":

O espírito da poesia me arrebata

Para uma região sem forma onde passo longo tempo imóvel

Num silêncio de antes da criação das coisas.

Súbito estendo o braço direito e tudo se encarna:

O esterco novo da volúpia aquece a terra,

Os peixes sobem dos porões do oceano,

As massas precipitam-se na praça pública.

Bordéis e igrejas, maternidades e cemitérios

Levantam-se no ar para o bem e para o mal.

Os diversos personagens que encerrei

Deslocam-se uns dos outros, fundam uma comunidade

Que eu presido ora triste ora alegre.

Não sou Deus porque parto para Ele,

Sou um deus porque partem para mim.

Somos todos deuses porque partimos para um fim único.

(A poesia em pânico, PCP.,p.,285)

Esse texto nos lança num universo onde as imagens se desdobram e se confundem, escondendo o ponto de partida, a imagem verdadeira. O texto reflete uma plena e ousada consciência do salto metalinguístico que quer capturar o senhor da linguagem, o poeta, no ser de linguagem, o poema. Vê-se aqui o ir e o vir do discurso 
poético entre os espaços existenciais do real e do simbólico. É um jogo de espelhos próprio da arte moderna, que atrai para a sua órbita tanto a transfiguração do real em linguagem como a transmutação da linguagem em realidade intrínseca, que subsiste a partir da sua própria base simbólica.

"Poema visto por fora" além de apontar o espaço anterior à criação, traz a vida investida no cenário do poema, no ato da linguagem que se forma para formar o homem e o mundo. O homem que expõe a sua consciência para que atinja o outro, a consciência do poeta que baila no palco de sua comunidade.

O braço direito que se estende, "tudo se encarna" e constrói o espaço existencial em sua plenitude é uma imagem da própria escritura; o texto poético, palco da manifestação de si mesmo, do poeta e de seus personagens, é também palco da confluência de mundos: do humano e do divino. O poeta constrói uma cena de reflexos cambiantes na qual ora funde, ora confunde as imagens representativas dele e de seu mundo, com as imagens do próprio poema.

A força que arrebata o poeta para fora do texto é o desejo narcísico do autoconhecimento. Essa mirada narcísica busca construir, a partir de referenciais internos, um espaço positivo para a existência em meio à "região sem forma" de um mundo que ameaça imobilizar o poder criador.

A exemplo do que ocorre nesse poema, grande parte da obra de Murilo Mendes traz o estigma de auto-referência refletida na estruturação metalingüística, sobretudo, na emergência simbólica do texto. A dimensão narcísica ganha, na poesia de Murilo Mendes, uma relevância expressiva na própria imagem poética. Nesse sentido, o caráter narcísico impõe-se como arquétipo mítico que busca dar conta de questões fundamentais do escritor e da escritura, ou seja, a busca de autoconhecimento num mundo caótico, desprovido de referenciais que assegurem a plena manifestação do ser em sua integridade individual. Cabe ao poeta encontrar esses referenciais, buscá-los a partir do interior do seu próprio ser simbólico, e do ser de linguagem, o poema.

Não basta, como o inocente Narciso, olhar-se no espelho para se encontrar. Nesta mirada para dentro de si mesmo, o poeta deve ser um decifrador de enigmas, um operador metalingüístico que penetre no reino sagrado da palavra original, a qual, na 
modernidade, se é criadora, também, desconfia, questiona. É uma palavra portadora da consciência existencial, ainda que essa existência se apresente vazia de sentido.

Já na proposta do poema "Beira-mar", poderíamos dizer, que há a busca de um caminho que leve ao lago de Narciso, um lago cujas águas possam refletir imagens do ser - do ser do poeta e do ser da linguagem. Podemos observar, já a partir das várias afirmações de busca por respostas, que os caminhos que levam ao autoconhecimento estão bloqueados. Há trevas, posto que as luzes são ambíguas. O enigma da esfinge não corresponde à sua natureza; a consciência projeta-se na indefinição do som das ondas alteradas pelas idas e vindas. Há uma total perda dos referenciais simbólicos que poderiam conduzir ao pleno exercício da vida. Conseqüentemente, o ser não mais encontra a sua identidade, deslocado que está do seu tempo-espaço vital, local de integração do ser consigo mesmo e com o mundo circundante.

A "esfinge prepara lentamente/ o avesso de sua resposta", e obriga o eu lírico a internalizar a contradição e construir a sua trajetória poética. O poeta, com o poema, deve encontrar o seu espaço significante, a sua razão de ser, no meio da crise de representação que abala os alicerces do mundo moderno, numa luta incessante contra o caos da ilegitimidade da resposta ou mesmo do apelo às ondas.

Em outro poema, "Conhecimento", o centramento da consciência existencial do ser é mais ostensivo, denso e dramático. Parte-se o espelho de Narciso: em seu lugar, surge o drama de uma crise de identidade que tende a imobilizar o ser no campo de forças de uma questão fundamental - "Quem sou eu? - para sua integridade existencial. Apesar de o ser encontrar respostas, ao repetir a pergunta no quinto verso é como se não houvesse caminho de volta desse cenário apocalíptico onde o poeta indica "ao navio de poetas o caminho do pânico", que ameaça o futuro diante da perda das próprias referências primordiais: "a sombra ambulante de meus pais", "o cérebro deixado em pasto aos bichos".

Mas o caminho de volta ao enigma e às imagens perdidas, sabe o poeta, é o percurso do próprio poema, com suas formas instauradoras de símbolos e signos ativos da consciência existencial. Assim, em sua ânsia de identidade, de referências simbólicas 
vitais, ao estender "os braços para separar o tempo", o poeta passa a sentir o fluir temporal como uma possibilidade de eternizar o instante.

O desespero que acomete o eu lírico em "Conhecimento" se condensa numa só questão: "Quem sou eu? Essa é a pergunta que a poesia de Murilo Mendes persegue dentro desse universo simbólico do arquétipo de Narciso. Essa pergunta, de um lado, modula a dramática busca de identidade do poeta, e, de outro, a visão imanente e autoreflexiva do poema. Os dois (poeta e poema), articulados esteticamente, apagam as fronteiras entre o ser e o reflexo. A natureza de cada um apresenta apenas a sua face no intercâmbio com o outro. Narciso não existe sem sua imagem, e esta não subsiste sem aquele. Daí porque é capital ao poeta e à poesia moderna a questão básica do eu em sua integridade simbólica, o drama da perda e da busca de referências que permitam o reencontro consigo mesmo e com o mundo como imagem. Qual Narciso enlouquecido, poeta e poema desconfiam das imagens refletidas nas plácidas superfícies do tempo unificado, separa os tempos e mergulha nas violentas águas da existência, num embate colossal do ser consigo mesmo e com o seu tempo, sua História.

No arquétipo mítico de Jacob, conforme foi atualizado pela poesia de Murilo Mendes, vimos a busca de materialização do sentido poético e existencial dentro de uma ordem redundante das possibilidades do ser e de manifestar-se do poeta e do poema. $\mathrm{O}$ texto é marcado pela articulação de uma escada-palavra metalinguística que possibilita a ascensão e queda da palavra poética num movimento incessante em busca de sua expressividade. Ao assumir esta forma de ser, a poesia, no seu movimento de subir e descer, transcende as margens do nonsense e instaura o sentido existencial no processo ascendente e descendente infinito. Torna-se existência e resistência. Universaliza-se. Redime-se.

$\mathrm{Na}$ atualização do mito de Narciso, viu-se um ser poético debatendo-se nas tensões simbólicas do texto em busca de imagens de si e do mundo. A visão narcísica, característica de toda poesia moderna, agora eleva-se como ponto de convergência das buscas fundamentais do poeta e do poema. Nesta visão, em que todo o olhar busca se ver e se conhecer, o texto poético funciona como um dínamo gerador de imagens e reflexos no horizonte textual, poético e humano. 
Observamos, então, no desenrolar-se desses três arquétipos míticos, que mito e modernidade se entrecruzam, se articulam dialeticamente na poesia de Murilo Mendes para que esta possa dar conta da autoconsciência desesperada do autor que busca incessantemente restaurar a poesia.

Com o eu muriliano estamos sempre diante de um ser a nos tornar interlocutores de seus desesperos e suas alegrias, de suas memórias e de suas esperanças, de suas tradições e de suas filosofias, abrindo um ardente espaço de troca no universo modernizado de homens divididos e de relações reificadas.

Assim, a expressão de todos esses elementos num universo poético, sob uma perspectiva mística-religiosa, oferece uma alternativa para o desolado quadro de falência das utopias da modernidade, posto que Murilo Mendes ordena em O Discípulo de Emaús: "recolhamos da tradição o que é espiritualmente vivo - e queimemos suas formas caducas".

\section{REFERÊNCIAS}

ARRIGUCCI, Davi. O escorpião encalacrado. São Paulo: Perspectiva, 1973. BRUNEL, Pierre (org.). Dicionário de mitos literários. Rio de Janeiro: José Olympio. 1977

CANDIDO, Antonio. Na sala de aula. São Paulo: Ática, 1989.

GUIMARÃES, Júlio Castanõn. Murilo Mendes: a invenção do contemporâneo. São Paulo, Brasiliense, 1986.

STEGAGNO, Luciana Picchio. (Sel. e org.). Murilo Mendes: Poesia Completa e Prosa. Rio de Janeiro, Editora Nova Aguilar, 1994. 


\title{
O imaginário da morte repousante em Hilda Hilst
}

\author{
Enivalda Nunes Freitas e Souza (UFU)
}

RESUMO: A crítica do imaginário estuda a hermenêutica dos símbolos, das imagens e dos mitos no processo da criação literária, vendo neles um esforço poético de resgatar o homem de sua temporalidade. Segundo Gilbert Durand, que elaborou a teoria dos regimes Diurno e Noturno das imagens, o regime noturno promove a junção das forças opostas, o que leva à valorização da morte como intimidade e repouso. Neste sentido, determinados símbolos em Hilda Hilst são reveladores dessa postura de domesticação da morte. Neste trabalho, observamos que os "símbolos da intimidade", como a terra, a casa, o ovo, a barca, são revestidos de uma hierofania que consagra a morte como renascimento.

PALAVRAS-CHAVE: Hilda Hilst; Gilbert Durand; Jung; Morte; Símbolos.

ABSTRACT: The criticism of the imaginary studies the hermeneutics of the symbols, the images and the myths in the process of literary creation, seeing in them a poetic effort to rescue the man of his temporality. According to Gilbert Durand, who developed the theory of the schemes Daytime and Night-time of the images, the nighttime scheme promotes the junction of the opposite forces, which leads to the valorisation of death as intimacy and rest. That way, certain symbols in Hilda Hilst show that posture of domestication of death. In this study, we observed that the "symbols of intimacy", such as the land, the house, the egg, the boat, are coated with a hierophany which consecrates death as rebirth.

KEYWORDS: Hilda Hilst; Gilbert Durand; Jung; Death; Symbols.

Em sua monumental obra As estruturas antropológicas do imaginário, Gilbert Durand colhe e organiza imagens de culturas as mais variadas. Ao organizá-las, o estudioso percebe que essas imagens se dividem em dois grandes grupos, pois seguem duas tendências distintas. Durand dá a essas estruturas o nome de regimes, o diurno e o noturno, seguindo a orientação filosófica de observar o universo em composição binária. As imagens desses regimes se apresentam formando uma cadeia simbólica numerosamente reduplicável, isto é, vão formando constelações. Desta forma, o termo estrutura se instaura somente com o sentido de "forma transformável". Ao formar constelações, as imagens seguem uma direção, configurando duas formas de se estar no 
mundo: uma que vê o universo dividido em opostos (morte/vida, bem/mal), caracterizando o Regime Diurno, e outra que procura unir os opostos, promovendo uma harmonização entre eles. Esse Regime é o Noturno, cuja presença da noite favorece a conciliação. Os dois regimes do imaginário, as imagens que os compõem, expressam e dão resposta à maior angústia do homem: sua mortalidade. Pelo trajeto antropológico, isto é, pela conjunção da subjetividade com os elementos sociais e cósmicos, as imagens que o homem produz revelam se sua postura é de combate às forças tenebrosas do tempo ou, se, por antífrase, é atenuante, postura daquele que recebe a ameaça da morte como quem caminha rumo ao aconchego e à intimidade.

\section{O Regime Noturno místico}

O Regime Noturno da imagem, aquele que se esforça por fundir e harmonizar as contradições que envolvem os homens, apresenta-se de forma mística e sintética e, em ambos os casos, trata-se de um mergulho na intimidade na tentativa de alcançar conhecimento.

Segundo Durand, o termo místico deve ser entendido em seu sentido comum, "mais vago e menos científico": "Daremos ao adjetivo místico o seu sentido mais corrente, no qual se conjugam uma vontade de união e um certo gosto da intimidade secreta”. (DURAND: 2001, 269). Marcado pela inversão (a capacidade de transformar símbolos negativos em positivos), o regime noturno místico será regido pelas estruturas do "redobramento e perseverança", e suas conseqüentes "viscosidade e adesividade", além das estruturas do "realismo sensorial" e da "miniaturização". Sobre "redobramento e perseverança", Durand afirma: "Há na profundidade da fantasia noturna uma espécie de fidelidade fundamental, uma recusa de sair das imagens familiares e aconchegantes" (269). Atualmente, não só a crítica psicanalítica admite que um autor trabalha com poucos temas, dedicando-se a modulá-los ao longo de suas produções. De igual forma, é consensual que o autor prima pela eleição de determinados elementos simbólicos.O leitor familiarizado com a obra poética de Hilda Hilst reconhece em seus versos sua fidelidade e predileção por certas imagens, tais como cavalos, tigres, onças, casas, pátios, cama, terra, barcos, e suas constelações simbólicas. 
O redobramento e a perseverança oferecem outra característica: a "viscosidade", a "adesividade", estrutura que confirma a variação temática recaindo sempre sobre um mesmo significado: "Esta viscosidade do tema traduz-se não por uma exata repetição estereotipada de uma interpretação dada, mas por variações temáticas que evidenciam o isomorfismo das interpretações" (270). Aqui, nada mais se tem do que a estrutura do encaixamento: da cama à casa, da casa à terra e da terra ao barco-túmulo. Nestas imagens, Hilda Hilst manifesta sua fidelidade à visão da morte como repouso, quietude, força outrora tenebrosa que se faz amiga e inevitável, portanto, possibilidade de recomeço ou de aquiescente retorno ao estado primitivo das coisas.

O tema da morte está na poesia de Hilda Hilst desde suas primeiras produções: Presságio - poemas primeiros, de 1950; Balada de Alzira, de 1951 e Balada do festival, de 1955. Pode-se dizer que nestes três primeiros livros (reunidos pela Globo em único livro sob o título de Baladas, em 2003), o tema da morte é fruto de uma "filiação poética". Com o tempo, transforma-se em tema afetivo, indissociável da longa experiência poética e dos anos que vão se passando.

Durand avança na percepção da característica da viscosidade e o alça a outros espaços:

"Esta viscosidade manifesta-se em múltiplos domínios: social, afetivo, perceptivo, representativo. Já vimos como a viscosidade do tema era importante, dado que ela dita um pensamento que deixa de ser feito de distinção e passa a sê-lo de variações confusas sobre um único tema" (271).

No domínio social, o artista desta característica é pouco dado a dissociações: gosta de fazer amigos e acolhê-los em sua casa, uma vez que a própria casa passa a ser uma "comunidade", uma "vila" de eleitos, um espaço construído para esse fim. Todos sabemos que Hilda Hilst construiu a Casa do Sol com fim específico de dedicar-se plenamente ao exercício da literatura. A Casa do Sol transformou-se em espaço afetivo de irradiação da cultura e da amizade. Durand sublinha que essa predisposição ao aglutinamento é própria do eufemismo, da antífrase que converte a experiência dolorosa da morte em renascimento:

“a vocação de ligar, de atenuar as diferenças, de subutilizar o negativo pela própria negação é constitutiva deste eufemismo levado ao extremo a que se chama antífrase. Na linguagem mística tudo se eufemiza: a queda torna-se 
Por fim, compondo o Regime Noturno místico temos as estruturas do "realismo sensorial" e da "miniaturização". O realismo sensorial é marcado pela vivacidade das imagens: o artista vai além da descrição; sua força imaginativa é capaz de deformar as imagens conhecidas e inaugurar outras; sua criatividade penetra, anima e reabilita as imagens. Por sua vez, a estrutura da miniaturização, ou o processo de gulliverização, apresenta o amor pelo detalhe: "é no Regime Noturno da imagem, pelo jogo dos encaixes sucessivos, que o valor é sempre assimilado ao último conteúdo, ao mais pequeno, ao mais concentrado dos elementos". (276) Ora, certamente são estas duas estruturas as mais indissociáveis da composição poética, pelo poder que tem o poema de revigorar o imaginário, ao inaugurar a cada imagem um sentido novo, e pelo extraordinário poder de captar o macrocosmo com a magia de uma única metáfora.

Em sua obra Literatura e antropologia do imaginário, Maria Zaira Turchi relê os gêneros literários sob a perspectiva das estruturas simbólicas do imaginário e estabelece para o gênero lírico as mesmas noções do regime noturno místico, porque, dentre outras afinidades, o modo de ser do lírico é, em essência, místico, uma vez que ambos revelam o mundo como emoção. Diz a autora

"No lírico e no místico, as ligações e as fusões infinitas são organizadas pela atitude repetidora da consciência, capaz de transformar o ruído do mundo em melodia, reduzindo a distinção entre a palavra e a coisa e buscando o indizível do momento simultâneo da imagem". (2003, 63)

Temos observado que o imaginário da morte em Hilda Hilst obedece ao princípio de eufemização, portanto, está associado ao Regime Noturno místico do imaginário, segundo o qual a tendência do ser humano é exorcizar as forças tenebrosas do tempo não pela antítese polêmica e implacável da separação que caracteriza o Regime Diurno das imagens, mas promovendo a junção das forças opostas, o que leva à valorização da morte. 


\section{Os símbolos da morte repousante}

A obra Da morte. Odes mínimas (2003) representa um esforço da poeta em colocar o sujeito em atitude de enfrentamento com a morte sem a espada na mão. Os elementos simbólicos ali presentes são reveladores de uma postura de domesticação da morte, representada sobretudo pelos animais, símbolos terrificantes por excelência, que surgem dóceis e íntimos: o cavalo infernal converte-se em cavalinha e seu tropel anunciador do momento tenebroso não se ouve, porque seus cascos estão enfaixados. Essa atitude de eufemização da morte vai-se desdobrar ao longo da obra, quando a poeta os abandona em favor dos "símbolos da intimidade", como a casa, a terra, o pátio, a mandala, a barca e o ovo, todos símbolos de uma mesma constelação hierofânica que consagra a morte como renascimento. Essas imagens-símbolos da intimidade expõem o desejo de mergulhar na morte e conhecer o seu mistério; significam valorizar a morte e exorcizar sua presença tenebrosa e terrificante.

Nos poemas que sucedem ao "pequeno bestiário" de abertura, em que ainda se observa uma presença maciça e mais volumosa da morte pela recorrência de animais primitivos como rinoceronte, elefante, malgrado sua domesticação, a morte será vista como recomeço, nascimento e reintegração ao estado primitivo, ou, nas palavras de Freud, restauração de "um estado anterior de coisas". Verificaremos nesses poemas a vontade de união, de penetrar fundo, em gestos que sempre revelam a morte em "desvantagem", porque a esta pertence só um momento, um brevíssimo instante, ao passo que o sujeito-lírico sempre viveu intensamente, como afirma nestes versos:

\footnotetext{
Imagina-te o que perderás

eu que vivi no vermelho

Porque poeta, e caminhei

A chama dos caminhos

Atravessei o sol

Toquei o muro de dentro

dos amigos.
}

É com esse mesmo ir mais além, romper as muralhas que guardam a mais secreta intimidade, que a poeta se ampara para reconhecer a morte como companheira, como inferior à força palpitante da vida. Quem foi tão fundo não teme quem se mostra em superfície ou, em profundidade, sempre mascarada, de tal forma que atingi-la é encarar as próprias profundezas e suas origens primordiais. Se a morte é funda, no mais 
profundo do osso, se é torsão de todas as funduras, a poeta também é de fundura de poço, por isso, íntima a pretende, instigando-a: "Dentro do meu ser / afunda-te, / dentro do meu sofrer". Da procura constante pela morte, restaram suas "funduras".

\section{A terra}

O caminhar constante para as profundezas do íntimo leva à elaboração de imagens consteladas que remetem à origem, à segurança, ao renascimento, ao desdobrar-se infinito de imagens de repouso e intimidade que sugerem a eufemização do aspecto tenebroso e irreversível da morte em conforto e quietude. Assim, já no segundo poema aparece a imagem da terra, a matéria/imagem que encerra em sua essência o repouso, a intimidade e a profundidade. No nível do inconsciente, voltar à terra é voltar à mãe, é restabelecer a união primordial, conforme seus versos: "Que eu te conheça lícita, terrena / Que me tomes sem pena, / Mas voluptuosa, eterna / Como as fêmeas da Terra". Grafada com "t" maiúsculo, a terra representa uma morte que se faz fêmea, genitrix; mais do que sepulcro, a terra é berço que embala, colo que acalanta e solo que germina a vida, repondo-a à condição primordial do Princípio absoluto. A morte imaginada como "fêmea" e "terra" é isomórfica da intimidade materna, da promessa do aconchego, certezas que exorcizam a presença terrificante e maléfica da morte. Esse devir é reforçado pela volúpia sagrada que só sabem ter as fềmeas no seu poder de preservação da vida. Logo, morrer assim é uma antífrase da morte, é celebrar a vida.

\section{A casa}

$\mathrm{Na}$ constelação de imagens que projetam a morte na intimidade, a imagem da terra é correlata à imagem da casa que, por sua vez, remete à morada primordial. A imagem da casa, impregnada de convite ao retorno e ao recolhimento, é engenhosamente construída em um poema instigante, do qual cito algumas estrofes: 
E escadas, tuas rijezas Vezenquando te volteias

Para que eu não me esqueça Casa e começo, tua cara,

A qualquer tempo te reconheço.

Mesmo para quem concebe a morte como um ato eufemizante das durezas da vida, uma possibilidade de penetrar um mistério inquietante, observar esse incômodo inquilino fazer moradia em seu próprio quintal, sentindo a cada dia a proximidade da construção pronta a ser habitada, não afasta o temor que obriga à vigilância. Afinal, quem ousou ser Menipo, o que ri e zomba da morte e de seus mensageiros? Assim é que, à medida em que a construção se desenvolve, lenta, é bem verdade, a morte, já na condição de senhoria, marca presença, vezenquando te volteias, e o sujeito, sempre apto a prestar contas, a espia de hora em hora.

Mas antes de falar da casa como primeira morada, quero registrar a comoção perturbada que este poema me causou por seu forte poder de persuasão, isto é, a morte, sempre imaginada em sua riqueza metafísica e filosófica, por isso difícil de ser representada, quando se quer fugir à alegoria. Aqui ela é presentificada com tal intensidade que não se acaba a leitura do poema sem a certeza de sua presença concreta em nossas vidas. Certamente, a persuasão deriva das imagens materiais com que a poeta edifica o tema. Segundo Bachelard, "as imagens materiais transcendem (...) de imediato as sensações (...) As imagens materiais nos envolvem em uma afetividade mais profunda, por isso se enraízam nas camadas mais profundas do inconsciente. As imagens materiais substancializam um interesse. Essa substancialização condensa imagens numerosas, variadas, nascidas freqüentemente em sensações tão distantes da realidade presente que parece que todo um universo sensível está em potencial dentro da matéria imaginada (1990: 3)". Telhas, tijolos, madeiras, essas matérias tão concretas e elementares, mais as etapas da construção, vão-nos dando a sensação de que, ao edificar a vida, também estamos edificando a morte, tão certa, real e rija como uma telha e uma madeira.

Ao final do poema, quando casa faz par com começo e ambas personificam a "cara" da morte, "Casa e começo, tua cara, / A qualquer tempo te reconheço", a desconfiança ou o temor parece dissolver-se, porque, ao lado de "começo", "casa" recupera a imagem primordial do repouso, do renascimento e do conhecer-se a si mesmo, uma vez que a ambivalência da casa-corpo não pode ser negligenciada, 
conforme atesta Durand: “Os poetas, os psicanalistas, a tradição católica ou a sabedoria dos dogon fazem coro para reconhecer no simbolismo da casa um duplicado microcósmico do corpo material e do corpo mental" (2001: 243). Assim, o que somos está na nossa casa-corpo. A casa evoca a descida nas lembranças, o silêncio da reflexão ou o barulho da alegria, imagens que revelam a intimidade e o eterno recomeço, possível quando se desce às suas profundezas. Essa casa primordial, em que morte e vida se fundem no infindável "começo", é a casa onírica, que vive em nós, de que fala Bachelard: "A casa oniricamente completa é a única onde se pode viver os devaneios de intimidade em toda a sua variedade. Nela se vive só" (1990: 81). Assim concebida, a casa se torna o espaço feliz, o "centro paradisíaco"; habitá-la é voltar à casa da mãe, à terra natal, para começar. Vista como símbolo do trajeto psicológico, da construção de si, a casa é isomórfica da casa-corpo; por isso é preciso ver a casa como um lugar santo, assim como o corpo é um tabernáculo; é santo porque é refúgio, receptáculo, "o nosso centro propriamente dito" (DURAND, 2001: 246). Quando se deita para receber a morte, o sujeito-lírico a recebe como quem retorna ao lugar sagrado, protegido, como está no verso de outro poema: "E sonho pátios, guetos / E então te abraço". Sonhar assim a morte é sonhar uma morte feliz.

\section{A mandala}

A união de dois princípios opostos mas complementares, morte/vida, faz parte do desenvolvimento psíquico que, como a psicologia jungueana deixa claro, se exprime por símbolos. Dentre tantos símbolos de união, as mandalas se destacam por seu caráter de totalidade sagrada. Observando as mandalas desenhadas por doentes mentais, Jung escreve: “Os próprios pacientes quase nada podem dizer acerca do sentido simbólico das mandalas, mas se sentem fascinados por eles. Reconhecem que exprimem algo e que atuam sobre seu estado anímico subjetivo" (2002: 30) e, em páginas seguintes, completa: "O movimento circular também tem o significado moral da vivificação de todas as forças luminosas e obscuras da natureza humana, arrastando com elas todos os pares de opostos psicológicos, quaisquer que sejam. (33) Sonhar pátios e guetos é sonhar lugares fechados e, conseqüentemente, buscar a intimidade feliz e protegida, símbolo da totalidade que som a morte e seu caráter reintegrativo pode oferecer. Segundo Durand, o que sacraliza um lugar é seu fechamento (2001: 246), sua separação de um mundo ausente ao sagrado. Desta forma, "pátios e guetos" são centros revestidos 
da simbologia da casa e seu simbolismo de intimidade e totalidade, de paz e segurança. O abraço, símbolo mandálico por excelência, pela sua circularidade, evoca o refúgio natural, o tempo infinitamente suspenso e o retorno ao ventre feminino que, de alguma forma, está entrevisto no ato de deitar-se, formando uma constelação simbólica do repouso e da profundidade.

Durand associa o círculo, o centro "à grande constelação do Regime Noturno, que é a repetição. Como o espaço sagrado se reduplica indefinidamente, ele está associado à repetição primordial, ao tempo sagrado. Assim, morte é centro, princípio e fim intermináveis, por isso, razão do canto, que também se situa na esfera do sagrado:

Por que me fiz poeta?

Porque tu, morte, minha irmã,

No instante, no centro

de tudo o que vejo.

No nó de um ínfimo laço ... à minha volta

Te vejo

Centro, laço, volta... sempre de volta ao começo.

\section{O peixe}

A idéia da totalidade sagrada da morte que vai sendo elaborada ao longo do livro ainda se manifesta no poema em que a morte se apresenta tal como um peixe lilás e malva em águas claras. Esse peixe simbólico é o próprio sujeito poético que, no decurso da vida, vai sendo preparado para o mergulho definitivo:

E fios e linhas

Trançando máscaras

Para a minha cara:

Rubro mandala

Para um perfil. Então ajusto

Para o mergulho

Os principais símbolos desses versos estão ligados a uma circularidade sagrada. Da água já sabemos de sua dupla natureza, que ela mata e revivifica, conforme atesta estudiosos do imaginário, mas fiquemos com a opinião de Jung: "Uma vez que a água 
procurada e necessária representa um ciclo de nascimento e morte, todo processo, consistindo em morte e renascimento, significa a água divina." (2002: 104). De igual modo ambivalente é o símbolo do peixe, considerando a dupla natureza de sua origem bíblica: Leviatã, um ser alado das águas profundas que se desdobra em Beemot, o ser quadrúpede. Certamente, essas imagens desdobradas se completam, como o consciente e o inconsciente, a morte e a vida, conforme Jung: "neste sentido, Leviatã e particularmente Beemot representam estágios do desenvolvimento da consciência e portanto de uma assimilação do homem." (1986: 112). Essa dupla natureza que o peixe evoca está nos dois últimos versos: "Sou eu. Um peixe rubro / E um outro lilás e malva".

\section{O fio}

Nesses versos finais, ainda temos "fios" e "linhas", símbolos cíclicos, sobretudo do devir e do recomeço, sejam eles os fios de Penélope que prolongam o tempo ou a linha do destino fiada pelas Parcas. Esse tecido de fios e linhas, que gerou a mandala de sua máscara (outra forma de encarar o tempo), é o invólucro preservativo da intimidade, conforme atesta Durand: "Decerto o tecido, tal como o fio, é antes de mais um ligador (lien), mas é também ligação tranqüilizante, é símbolo de continuidade, sobredeterminado no inconsciente coletivo pela técnica "circular" ou rítmica da sua produção. O tecido é o que se opõe à descontinuidade, ao rasgo e à ruptura." (2001: 322) Dentro desse sentido de continuidade do tempo, as linhas trançadas, formando uma máscara-mandala, não deixam de evocar os invólucros preservadores da vida, como o das múmias e o das lagartas, separação e proteção ritualística e sagrada a partir da qual a vida poderia se renovar.

\section{O barco}

Para finalizar, ressalto uma última imagem de repouso, quietude e intimidade muito freqüente em Hilda Hilst, que expressa a situação atenuante de enfrentamento da morte: a imagem do barco. Se morrer é voltar para casa, a acolhedora terra-mãe, o barco sempre foi o primordial veículo dessa viagem. Como estamos falando de um retorno feliz, não evocamos a barca de Caronte ou os navios fantasmas, que transportam ou 
atormentam as almas. A barca de Hilda Hilst é a que conserva a alma para levá-la ao repouso eterno, barca agora convertida em poesia:

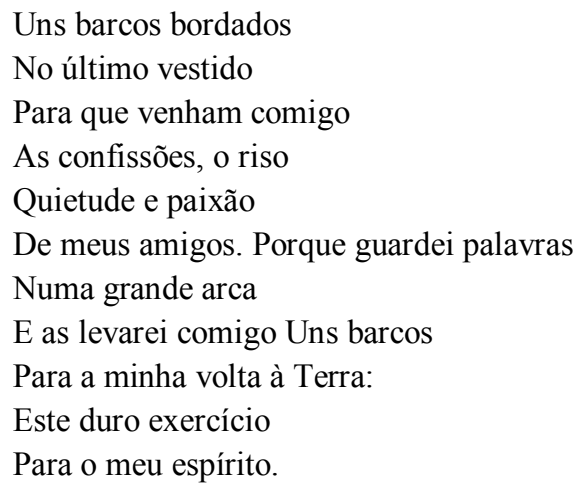

Todo exercício de retorno é duro, porque a viagem é uma travessia - lembremos da aventura de Ulisses - , mas também não nos esqueçamos da intimidade triunfante da barca, como aquela que conservou um destino feliz para Moisés e para o "nosso pai" em “A terceira margem do rio". Podemos dizer que o sujeito destes versos parte como o "audaz navegante" de Brejeirinha, aquele que vai descobrir outros lugares, no embalo e na proteção de uma barca-berço que reconduz à intimidade materna. Assim, essas duas naves, a vida e a morte, e uma só pessoa, navegam rumo às origens, ao centro-ovo, espaço em que o ciclo se fecha e recomeça indefinidamente, porque no ovo contém o universo, e na sua intimidade uterina a vida se renova, gerando o homunculusalquímico, esse ser emblemático disposto ao crescimento.

BACHELARD, Gaston. A terra e os devaneios do repouso. São Paulo: Martins Fontes, 1990.

DURAND, Gilbert. As estruturas antropológicas do imaginário. São Paulo: Martins Fontes, 2001.

HILST, Hilda. Da morte. Odes mínimas. São Paulo: Globo, 2003.

JUNG, C. G. Estudos alquímicos. Petrópolis, RJ: Vozes, 2002. Aion. Estudos sobre o simbolismo do si-mesmo. Petrópolis, RJ: Vozes, 1986. ROCHA PITTA, Danielle Perin. Introdução à teoria do imaginário de Gilbert Durand. Rio de Janeiro: Atlântica Editora, 2005. TURCHI, Maria Zaira. Literatura e antropologia do imaginário. Brasília: UnB, 2003. 


\title{
Meditações da finitude em Ivan Junqueira
}

\author{
Alamir Aquino Corrêa (UEL)
}

RESUMO: O poeta Ivan Junqueira retoma um tema de Augusto dos Anjos ao tratar da morte como algo inevitável. O "saber a pêsames" enquanto estética denota a manutenção da elegia pastoral como forma poemática de grave interesse. A contemplação do silêncio mortuário enquanto reflexo de um eu-lírico ensimesmado corporifica a sua humanidade em tempos de desapego e de desprezo. O contexto é aquele de uma ressaca das mortes da Grande Guerra, de um afastamento do holocausto, quando parece esvaziada a noção da morte impensável da vida sem valor; por outro viés, é ele o poeta de uma melancolia exasperada pelo esvaziamento de um futuro inalcansável. A morte, em Ivan Junqueira, é motivo de uma tristeza incompreensível.

PALAVRAS-CHAVE: morte, poesia, Ivan Junqueira, luto.

ABSTRACT: The poet Ivan Junqueira retakes a theme from Augusto dos Anjos dealing with death as something inevitable. This taste of grief as an aesthetic denotes the maintenance of pastoral elegy as a poetic form of serious interest. The contemplation of the mortuary silence as a reflection of a self-absorbed I-lyric gives meaning to his humanity in times of disdain and indifference. The context is the undertow of the deaths during the Great War, of a removal from holocausto, when it seems to void the notion of the unthinkable death of life without value; for another bias, he is a poet of a melancholy enraged for the emptied and unreachable future. The death, in Ivan Junqueira, is the reason of an incomprehensible sadness. KEYWORDS: Death, poetry, Ivan Junqueira, grief.

Há algum tempo venho me dedicando a um estar-para-a-morte, na busca acadêmica de uma compreensão do impacto do tema na literatura e nas artes. Esse estar é menos uma consciência da finitude e mais uma afirmativa da arte enquanto aquela que nos revela a nós mesmos. Não creio que eu possa dar conta de tudo aquilo que li e deixei de perceber antes, ao retomar as percepções e impressões críticas ao longo de uma trajetória que se quer fazer já madura. Entretanto, antes de um ser-para-a-morte, quero continuar dizendo o que vejo de humano, talvez a condição mais diferenciadora do que somos, na morte enquanto tema e constância na arte, observando-a enquanto recurso estético que foge ao contexto da realidade extra-ficcional. Em suma, minha intenção é observar o objeto artístico, na esteira do estranhamento proposto por Viktor B. Shklovsky, enquanto manifestação crítica e reflexiva sobre a qualidade do humano.

A morte, enquanto fato social representado na literatura e nas artes, caminhou por várias searas e preocupações. Pode-se detectá-la na noção do julgamento do ser e do 
estar ainda na Antigüidade, especialmente entre os egípcios, no judaísmo (a oração recupera os pecados levando a alma para fora do Gehinnom, o nome dado na Torá ao espaço de espera e purga, para que entre no Gan Eden), já na primeira cristandade e no islamismo (Alá mudará o mal para o bem se houver arrependimento), quando a vida terrena organiza os destinos do além-da-vida. A idéia de uma atitude a ser punida está no fundamento da constituição da sociedade, de forma a propiciar a preservação mútua no convívio das cidades, respeitadas através da ética a propriedade e a vida.

Durante a Idade Média, muito em função de uma medicina claudicante ainda por demais ligada à crença nos desígnios divinos enquanto organizadores do destino dos homens e mulheres, mantida assim a noção de pecado para motivo de julgamento ainda em vida, surge uma percepção consoladora da morte coletiva, encontrável principalmente na pintura e na gravura, e retratada exemplarmente no Decameron de Boccaccio. Outro motivo recorrente, a Dança da Morte é a niveladora, pois todos podem ser levados pela Indesejada das gentes, desprezados o gênero, a condição social ou a idade. Fica sempre a noção da transitoriedade e do memento mori como articuladora da redenção de almas.

A morte na ocidentalidade chegou aos séculos XVIII e XIX como uma compreensão da individualidade libertária, principalmente através da consciência maior da razão científica, demonstrada pelas novas posturas urbanas (caso dos cemitérios e das vacinas) e entrou no século XX como o esvaziamento do indivíduo em prol de um anonimato proporcionado pelas grandes guerras. A memória coletiva se torna, especialmente enquanto monumento, o único registro simbólico daqueles que foram; pari passu, surge uma morte asséptica negadora do poder divino da medicina e distanciada da família e da tradição do vivente, reservando-se nos hospitais e asilos a solidão dos moribundos.

Formalmente, na ars moriendi representada nas obras artísticas, houve manifestações de júbilo, de orgulho, de indignação, de dó e terror, de continuidade e de espanto. Na singeleza dos infortúnios coletivos, aqui e ali pontuam as dores individuais tornadas banais ou desproporcionalmente insignificantes na sua totalidade singular, mas que juntas causam a sensação do horror em face do desumano. Na literatura, encontramse diversas formas que vão desde os gêneros públicos, caso do sermão, do elogio de 
corpo presente ou fúnebre e da oratio funebris, até os gêneros épico-narrativos (Memórias Póstumas de Brás Cubas e São Bernardo, por exemplo) e poético-líricos ("Cântico do Calvário" de Fagundes Varela e "Morte no avião" de Drummond). Nesse trabalho interessa-me, particularmente, a elegia enquanto forma poemática e o seu papel na modernidade.

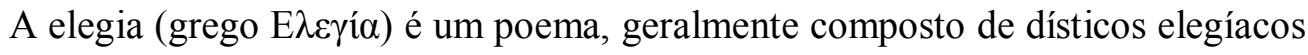
(hexâmetro seguido de pentâmetro), para expressar lamento na morte de alguém ou por vezes uma tristeza qualquer, no caso de guerra ou de amores; por vezes também há o treno (poema sobre o morto cantado em qualquer lugar, como é o caso de Ariel sobre o pai morto de Ferdinando em $A$ Tempestade[I.ii] e de Fidele/Imogen em Cymbeline [IV.ii] de Shakespeare) ou lamento. São conhecidas as seguintes variantes: nênia (canção sobre aquele que se foi cantada por pranteadoras) ou epicédio (poema lamentoso sobre o morto presente), endecha (Lapesa 1979: 145) ou romancilho (com versos curtos) e epitáfio.

A elegia é o constructo poético capaz de organizar dores, ausências e memórias, com a vontade de explicitar um possível alento aos deixados, na seqüência do ovidiano hora fugit, por vezes sendo usado em epitáfios, como é o caso registrado na Lira I de Marília de Dirceu: "Quem quiser ser feliz nos seus amores, / Siga os exemplos, que nos deram estes". A qualidade da elegia depende muito da aceitação do assunto nela contido pelo leitor como verdade e testemunho (Shaw 1994). Na literatura clássica, em razão de sua qualidade métrica há vários exemplos de elegias acerca da coletividade, como é o caso de Simonides de Ceos e Simonides de Amorgos, acerca dos heróis de Maratona e da Batalha das Termópilas: "Vá, diga aos Lacedemônios, passante, / que aqui obedientes a suas leis restamos" 1

Depois do Renascimento, a elegia assume - talvez em prol de um reconhecimento da individualidade - o caráter mais singular, como expressão de dor acerca da morte de um ente querido (Camacho Guizado 1969). Estabelece-se como um ubi nunc ou ubi sunt qui ante nos fuerunt, a perguntar onde estão aqueles que eram. Os lamentos por pessoas específicas são comuns, transformados na convivência moderna pelos testemunhos televisivos de dor do passamento de figuras públicas. 
A elegia geralmente busca sua constituição na variante pastoral, cuja origem remonta aos poetas clássicos Teócrito (Theocritus e "Thyrsis"), Moscos de Siracusa (Moscus e "The Lament for Bion") e Bíon de Esmirna (Bion e "The Lament for Adonis") (Edmonds 1912). Nela, o poeta e o pranteado são pastores, invocam-se as musas e entes mitológicos são trazidos como paisagem mesclada à Natureza, os guardiães do morto são questionados pelo poeta sobre o que faziam quando da visita da Morte, há uma procissão de lamentadores; o poeta então discorre sobre a justiça divina e as maldades, há uma cena da flor a emoldurar o esquife e finalmente percebe-se uma renovação da esperança, contida na morte o começo de nova vida (Cuddon 1992: 273). Na modernidade, o aspecto pastoral perde evidência, mas enfatiza-se a reflexão pessoal, como é o caso do longo poema "When Lilacs Last in the Dooryard Bloom'd" de Walt Whitman.

Recentemente, com a velocidade das informações mediáticas, talvez seja possível outro olhar, na esteira dos episódios começados com o 11 de setembro. Entretanto, o registro elegíaco parece ser a forma mais apropriada que a arte encontra para lidar com a emoção da finitude. Esse século tem, por variadas razões, um distanciamento do que se convencionou nas elegias fundadas no sentimento de redenção religiosa. Para compreender isso, ou seja, como uma forma ou um gênero criado em determinada necessidade transforma-se, enquanto ato de fala, visite-se a posição de Tzvetan Todorov em sua teoria da origem dos gêneros:

o fato de uma obra 'desobedecer' a um gênero não faz com que este desapareça; é tentador dizer que o contrário realmente é verdadeiro. E por uma razão de dois termos. Primeiro, por conta da transgressão, para existir como tal, necessita de uma lei que possa ser, claro, transgredida. . . . Mas há mais. Não apenas a obra, por ser exceção, pressupõe necessariamente uma regra; mas essa obra também, tão logo seja reconhecido o seu status excepcional, torna-se por sua vez, graças a boas vendas e atenção crítica, uma regra. $(160)^{\underline{2}}$

A elegia, na modernidade, tem a marca de outra qualidade, transgredindo as leis anteriores, a buscar não mais a da salvação mas a registrar aquela do desespero pela impossibilidade da aceitação do desumano. As guerras, em sua crescente capacidade destrutiva, separam a morte da esperança, pois nada resta; possivelmente, o artista deixa 
de acreditar na continuidade da vida para a morte, destruindo o continuum e enfatizando a dualidade entre vivos e mortos. A falência do humano é, em ultima res, a própria falência do divino, pois não poderia um Deus permitir tamanha desproporção quando o homem nega a sua própria humanidade; em termos formais, talvez possa se dizer que a modernidade não encontraria mais na elegia clássica um de seus fundamentos, na tradição pastoral, o locus amoenus. Há uma transformação, mantidas as condições:

\footnotetext{
Apesar das mudanças do motivo nas versões clássicas, cristã e romântica, emergem dois temas estáveis. Primeiro, o locus amoenus é sempre uma imagem poética imaginada, que permite ao poeta criar alguma versão de um reino ideal, que está bastante distante das dificuldades dolorosas do mundo real. Por meio da criação imaginária de uma paisagem desejada, o poeta realmente controla e transforma a sua rudeza em um lugar que é adequado à harmonia e habitabilidade humana. Segundo, o locus amoenus oferece um ideal que permanece inatingível pois existe apenas na linguagem. (Haas 1998: 673-74) $)^{3}$
}

A esperança de uma salvação torna-se improvável por sua inexistência, ou seja, o salvador torna-se imponderável diante de seu afastamento dos homens que se mostram desumanos - e não há como evitar a lembrança de En Attendant Godot, de Samuel Beckett. Mantém-se então não a esperança de uma salvação, mas a idéia utópica da esperança; não mais a esperança do que não se pode esperar, mas a esperança como possibilidade, não mais a ênfase na circularidade mas sim a verdade da vida como uma crueldade aceitável. Parece ter se perdido o conceito de morte como a transição entre o mundo real e o mundo místico. Talvez isso possa ser explicado pela efetiva participação da ciência e da razão no mundo moderno. Isso não caracteriza uma ausência de religiosidade; tampouco há elementos que sustentem um veio mais forte e firme acerca do comprometimento de uma moral a justificar a vida terrena em face de uma punição ulterior, ou seja, no além-da-vida.

Em síntese, percebe-se no contexto, uma dificuldade moderna de lidar com a morte, enquanto conceito de uma metafísica religiosa. Cada vez mais individulizante, a voz lírica discute o morrer e a morte, enquanto processos angustiados, tristonhos, melancólicos, como se nos faltasse o chão e permanecêssemos de pé. A inevitabilidade da morte, manifestada enquanto memória do ubi sunt,transforma-se em mistério indevassável, por falta de completo sentido da vida. Essa sensação caótica organiza-se, 
pelo paradoxo, pelo apego à vida, como se tivéssemos de dar um valor maior ao que temos vez que não há mais certeza do que teremos.

Por este ângulo, lembro aqui do poeta Ivan Junqueira que retoma, em várias de suas obras, uma tradição de Augusto dos Anjos ao tratar da morte como algo inevitável. A poesia de Ivan Junqueira é também inevitavelmente uma peça canônica, não apenas por seu percurso continuado de poeta, mas especialmente por sua sagração institucional. Jornalista, critico literário, ensaísta, tradutor de poetas pilares da modernidade (Baudelaire e Eliot), teve carreira pontilhada por prêmios expressivos, alcançando a eleição para a cadeira 37 da Academia Brasileira de Letras, sucedendo João Cabral de Melo Neto, também artífice do poema moderno. Sua obra poemática começa em 1964 com Os Mortos; desde então, publicou Três Meditações na Corda Lírica (1977), A Rainha Arcaica (1980), Cinco Movimentos (1982); O Grifo (1987); A Sagração dos Ossos (1994), Poemas Reunidos (1999); Os Melhores Poemas de Ivan Junqueira (2003) e Poesia Reunida (2005).

Sua fortuna crítica é composta principalmente de notícias em jornais; a sua técnica rítmica e o seu apuro melódico parecem ter encantado críticos que geralmente apontam os seus textos como essenciais, singulares, articulados, eivados de uma tradição da lírica luso-brasileira, mas bebendo em outras fontes, especialmente por sua convivência com os estrangeiros que traduziu. Seus leitores são parte do que tem sido a melhor critica literária dos cadernos "dois" dos jornais brasileiros desde a década de 60; cito entre vários por ordem de sobrenome Almeida Fischer, Assis Brasil, Walmir Ayala, Ivo Barroso, Aurora Bernardini, Rubem Braga, Alexei Bueno, Antonio Candido, Geir Campos, Otto Maria Carpeaux, José Castello, Edilberto Coutinho, Fausto Cunha, Helena Parente Cunha, Paulo Francis, José Lino Grünewald, Antônio Houaiss, Ledo Ivo, Bella Joseph, Leandro Konder, Stella Leonardos, Oswaldino Marques, Wilson Martins, José Guilherme Merquior, Carlos Nejar, Antônio Olinto, Fernando Py, Olga Savary, Donald Schüller e Elizabeth Veiga. Saltam aos olhos, entretanto, três textos tipicamente acadêmicos: Gilberto Mendonça Telles e seu artigo "As Duas Vozes do Poeta" especialmente ao tratar da técnica do parénthesis em Junqueira (prefácio de $A$ Rainha Arcaica), "O exato exaspero" de Antonio Carlos Secchin (prefácio de $A$ 
Sagração dos Ossos) e a dissertação de Ricardo Luiz de Souza, orientado de Secchin, "Uma poesia com vísceras: o palimpsesto poético de Ivan Junqueira".

Se é que é possível dizer algo de diferente, em face de tal fortuna critica, registro em Ivan Junqueira o "saber a pêsames" enquanto estética que denota a manutenção da elegia pastoral como forma poemática de grave interesse. Interessa-me assim observar a contemplação do silêncio mortuário enquanto reflexo de um eu-lírico ensimesmado, corporificando a sua humanidade em tempos de desapego e de desprezo. O contexto é aquele de uma ressaca das mortes da Grande Guerra, de um afastamento do holocausto, quando parece esvaziada a noção da morte impensável da vida sem valor; por outro viés, é ele o poeta de uma melancolia exasperada pelo esvaziamento de um futuro inalcançável. A análise que farei procurará evidenciar a morte, em Ivan Junqueira, como motivo de uma tristeza incompreensível.

Tite de Lemos, em 1964, ao tratar de Os mortos, levanta a idéia de que o poeta deve enfrentar a sua própria morte, de maneira intuitiva, pois cabe ao poeta "pensar o mundo" (268). Esta barreira, de fundo metafísico, sobre a finitude, amplia na modernidade a compreensão do constrangimento da solidão, enfrentável pelo mundo dos deixados. A tônica deixa de ser o ubi sunt do solitário e passa a ser a incompreensão da tristeza que os mortos nos causam, pela memória que deles carregamos, logo um hic sunt:

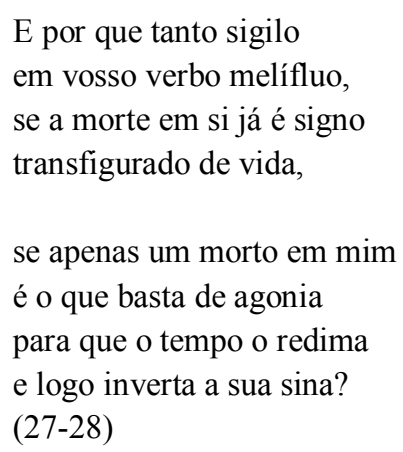

Lembro aqui de um dos poemas mais sólidos da contrição cristã na literatura brasileira, o soneto "A Jesus Cristo Crucificado estando o poeta para morrer" de Gregório de Matos. No caso, o soneto gregoriano estipula, falando com Cristo, "Se basta a vos irar tanto um pecado, / A abrandar-vos sobeja um só gemido"; também falando com o morto crucificado, Gregório organiza a sua relação de morte próxima. $\mathrm{Na}$ 
versão elegíaca de Junqueira, falando com os mortos, a memória do vivo ou do deixado se incomoda com a redenção dos mortos, nos vivos invertida a sua sina. Por outro lado, lidar com a morte, que para muitos pode soar como crueldade, é ter e recuperar a consciência da Todestanz ou Dance Macabre, pela convivência com o escatológico da memória que não os compõe na sua inteireza:

Lembro alguns, talvez meninos que se foram por equívoco; e outros mais, algo esquecidos que de sim mesmos se iam.

Mas estes, a que família de mortos pertenceriam? A que clã, se não os sinto Visíveis, tampouco extintos?

Ou quem sabe não seriam mortos de morte, mas sim de vida: imagens em ruínas na memória adormecidas. (26-27)

Esse momento da reflexão sobre a indissociabilidade entre a vida e a morte retorna em $O$ Grifo, apontada por Per Johns no prefácio desta obra. Talvez pela própria idéia de um grifo, guardião de tesouros, mistura de força e precisão, pautadas pela dureza dos golpes, o eu-lírico se afasta da festividade ritualística da morte para a crueza da realidade da morte, conjunto de efervescência da vida que destrói o que se foi, na destruição apocalíptica da revelação mais íntima e profunda: "Desde o princípio o grifo tudo arruína / — sonhos, idéias, êxtase, delírio — / e até no poema a sua língua bífida / enfia em busca do que lhe é mais íntimo" (142), infalível na sua espera:

(...). A grande ave,

Pousada sob os galhos, aguarda

Aquele que virá matá-la, para depois

Aos poucos devorar-lhe a inútil alma

E a carne consumir-lhe palmo a palmo (147)

Na mesma obra, Ivan Junqueira tenta dividir corpo e espírito em "Corpus meum" (148150). Propõe ele uma dualidade e não uma continuidade, como se pudéssemos separar uma coisa da outra, em contraste com o conceito de carnalidade enquanto invólucro, vil 
matéria que retornará ao pó ("pasto de vermes e moscas / que lhe degustam os livores. / Este corpo, este meu corpo... / Que a terra lhe seja fofa"). Lembra Cruz e Sousa em "Cárcere das almas" e até mesmo Fernando Pessoa no quinto poema de "As Quinas" de “O Brasão" de Mensagem, intitulado "D. Sebastião, Rei de Portugal" quando falando com um eu-lirico de D. Sebastião sobre sua loucura, pede que a vejam "Sem a loucura que é o homem / mais que besta sadia, / cadáver adiado que procria”.

A idéia de um julgamento fundado em regras compreensíveis e pré-acordadas deixa de ter substância. Alguns poemas mantêm a elegia como memória dolorosa ou como manifestação de carinho ao morto. É o que acontece em "Pompas Fúnebres":

(A quem pertence o espírito

desse corpo tão franzino

em cujas lívidas linhas

lê-se - último capítulo?)

A morte tudo ilumina,

Mesmo em pleno meio-dia

À sombra da pirâmide,

O tempo é como a areia

E lento se esfarinha. (183)

Uma tônica que perpassa vários poemas é a discussão sobre o morrer. Se antes era a noção do conforto ou do consolo aos deixados ou uma preventiva argumentação sobre a boa qualidade do morto em vida, passa tal preocupação a ser com o viver oposto ao não viver, como em "A Sagração dos Ossos":

Onde andaram? Em que solo deitaram sêmen e prole?

Foram químicos, astrólogos, remendões, físicos, biólogos?

Ou nada foram? Que importa não haja um só microscópio lhes cevado a magra forma ou a mais ínfima nódoa?

\section{Existiram. Esse é o tópico} que aqui, afinal, se aborda. E eis que o faço porque, ao toque de meus dedos em seus bordos

tais ossos como que imploram 
a mim que os chore e os recorde que jamais os deixe à corda da solidão que os enforca. $[\ldots]$

Baixa uma névoa viscosa Sobre as pálpebras da aurora. E ali de pé, sob a estola de um macabro sacerdote,

Sagro estes ossos que, póstumos, recusam-se à própria sorte, como a dizer-me nos olhos: a vida é maior que a morte. (262-263)

Outra tensão importante é a construção do depois do morrer. Lembro aqui que uma das características fundamentais da elegia é permitir que haja, mesmo em face do infortúnio da perda, uma esperança. A modernidade parece ter encontrado um formato especial - ao tratar da morte como um episódio individual mas não individualizado. $\mathrm{Ou}$ seja, a morte e a perda enquanto motivos do lamento se tornam mais universais no sentido de haver na voz lírica do poema moderno um foco no que ouve a sua fala. Ivan Junqueira nega uma após-a-vida, em “Morrer”, fazendo sentir que não há muito a dizer: "Pois morrer é apenas isto: / cerrar os olhos vazios / e esquecer o que foi visto" (313). O eu-lírico desmistifica a morte, organizando-a por sua completa falta de utilidade: "é talvez como despir / o que em vida não vestia / e agora é inútil vestir"; a vida mesma deixa de ser, a morte é, sem ser: "é findar-se como um círio / em cuja luz tudo expira / sem êxtase nem martírio" (314).

Nós, vivos, e nós, mortos, acabamos perdidos em nós mesmos, divididos entre o ser e o estar, o primeiro impossível e o segundo transitório - assim, resta-nos buscar conviver com o que nos sobra, lembrando que há uma ótica do deixar desde Mateus 8:21-22, que os mortos enterrem seus mortos, ou nas palavras do eu-lírico de Ivan Junqueira, em "O Enterro dos Mortos" (208):

Não pude enterrar meus mortos.

Sequer aos lábios estóicos lhes fiz chegar uma hóstia que os curasse dos remorsos.

Quero esquecê-los. Não posso: 
andam sempre à minha roda, sussurram, gemem, imploram e erguem-se às bordas da aurora

em busca de quem os chore ou de algo que lhes transforme o lodo com que se cobrem em ravina luminosa.

\section{Notas}

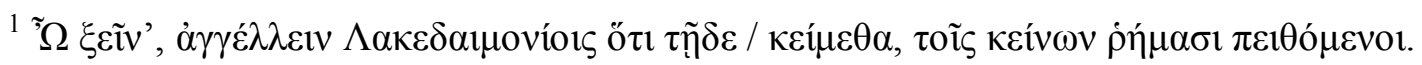

${ }^{2}$ The fact that a work 'disobeys' its genre does not make the latter nonexistent; it is tempting to say that quite the contrary is true. And for a twofold reason. First, because transgression, in order to exist as such, requires a law that will, of course, be transgressed. . . . But there is more. Not only does the work, for all its being an exception, necessarily presuppose a rule; but this work also, as soon as it is recognized in its exceptional status, becomes in its turn, thanks to successful sales and critical attention, a rule.

${ }^{3}$ Despite the changes in the classical, Christian, and Romantic versions of the motif, however, two stable themes emerge. First, the locus amoenus is always an imagined, poetic activity that allows the poet to create some version of an ideal realm that is far removed from the painful difficulties of the real world. By imaginatively creating the landscape of one's desires, the poet, in effect, controls nature and transforms its wildness into a realm that is suitable for human harmony and habitation. Second, the locus amoenus offers an ideal that remains unattainable because it exists only in language.

\section{Obras citadas}

Camacho Guizado, Eduardo. La elegia funeral em la poesia española. Madrid: Gredos, 1969.

Cuddon, J. A. The Penguin Dictionary of Literary Terms and Literary Theory. London: Penguin Books, 1992.

Edmonds, J. M. trad. The Greek Bucolic Poets. Loeb Classical Library Volume 28. Cambridge, MA. Harvard Univserity Press, 1912.

Haas, Robert Bernard. "The Mutable Locus Amoenus and Consolation Tennyson's In Memoriam."Studies in English Literature 1500-1900 38.4 (agosto 1998): 669-87.

Junqueira, Ivan. Poemas Reunidos. Rio de Janeiro: Record, 1999.

Lapesa, Rafael. Introducción a los estudios literarios. Madrid: Cátedra, 1979.

Shaw, W. David. "Elegy and theory: is historical and critical knowledge 
possible?" Modern Language Quarterly 55.1 (March 1994): 1-16.

Todorov, Tzvetan. "The Origin of Genres." New Literary History 8 (1976): 159-170.

Whitman, Walt. Leaves of Grass. Philadelphia: David McKay, [c1900]; Bartleby.com, 1999. Disponível em http://www.bartleby.com/142/192.html; acesso em 14 de junho de 2008 . 


\title{
A Imagem Poética e Fotográfica de Sérgio de Castro Pinto
}

\author{
Maria Marta dos Santos Silva Nóbrega (UFCG)
}

RESUMO: A imagem câmera de Sérgio de Castro Pinto em O Cerco da memória apresenta-se dissonante e anormal quando busca espaços de representação de uma outra realidade. O poeta faz uso de uma linguagem diferente na Retórica modernista e para enfatizar sua atitude, assume o ofício de fotógrafo. Este trabalho objetiva compreender como o poeta se situa no centro da modernidade ao fixar, em sua obra, os postulados da era da técnica. Nessa poética, a máquina é um instrumento frio, metáfora do homem nessa era tecnicista, que na medida em que cresce em consciência própria, vai internalizando o mundo objetivo, mudando-o poeticamente.

PALAVRAS-CHAVE: Sérgio de Castro Pinto, imagem, poeta fotógrafo.

ABSTRACT: Sérgio de Castro Pinto's camera image in O Cerco da Memória (The Siege of Memory) appears dissonant and abnormal as it finds room for representing another reality. The poet uses a different language in his moderninst Rhetoric, and in order to highlight his attitude, he acts like a photographer. This work aims to understand how the poet places himself in the centre of modernity as he establishes, in his work, the postulates of the technical age. In this poetics, the machine is a cold instrument, man's metaphor in this technicist age. As it grows in its own conscience, it keeps on internalizing the objective world and changing it poetically.

KEYWORDS: Prose poem; Lyrical poetry; Modernity; Modern literature.

Neste trabalho pretendemos comentar alguns aspectos estéticos da modernidade lírica utilizados por Sérgio de Castro Pinto em O Cerco da memória (2006) - livro que reúne poemas selecionados do livro homônimo publicado em 1993, de Gestos lúcido (1967), de A Ilha na ostra (1970) e de Domicílio em trânsito (1993). Para as reflexões dobre lirismo moderno, nosso apoio teórico será Benjamim (1983) e Friedrich (1991).

$\mathrm{Na}$ estética modernista vista por Walter Benjamim há, pelo menos, duas categorias centrais responsáveis por um novo conceito de autenticidade para a arte: a destruição da aura e a reabilitação da alegoria. Essas duas categorias estão ligadas aos fenômenos da reprodução mecânica e da perda da experiência. 
Os postulados benjaminianos quando aplicados aos estudos sobre fotografia, cinema, poesia de Baudelaire, ficção de Proust e outras modalidades do campo artístico anulam a eficácia mimética da arte. Para Benjamim, o novo da arte é revelado pela sua força de produção. Ao mesmo tempo em que a obra de arte se adapta ao público com o uso das facilidades técnicas, também desafia a este mesmo público visto apresentar um conteúdo pouco acessível, como é o caso de muitos poemas de Sérgio de Castro Pinto, a exemplo de "atos falhos", transcrito a seguir:

Atos falhos

sequer os ensaio.

mas os meus atos

falhos

encenam-se assim:

eles já no palco

e eu ainda

no camarim.

O poema expressa uma consciência de que no contexto da modernidade - em que predomina o paradoxo, "uma unidade de desunidade" (Berman, 1986:15) -, homem, realidade e linguagem não se encontram pacificamente no horizonte da representação. Em meio à proliferação de signos, a linguagem falhou.

Essa perda de uma perspectiva integralizadora da existência, essa crise de cisão entre homem e mundo, na concepção de Alfredo Bosi (1993:142), se dá por vários motivos, entre eles, está "a extrema divisão do trabalho manual e intelectual, a ciência e, mais do que esta, os discursos ideológicos e as faixas domésticas do senso comum[...]." Como sintoma desse estado de consciência, o esforço expressivo que cada poeta empreende figurará os contornos de uma negação própria, identificadora, refletida em cada imagem criada. O poeta moderno consciente de sua condição diante da sociedade, 
transforma sua expressão numa espécie de campo dilacerado para onde converge o descompasso que raia a existência cotidiana. O poeta, conforme Bosi (1993:151), tornase "demiurgo da própria existência, tenta abrir no espaço do imaginário uma saída possível". Não obstante as inquietações do mundo moderno, a poesia preserva sua natureza original, criativa, evocadora de essências simbólicas no plano do ser.

A imagem de "atos falhos", constitui-se instância fundadora na percepção de Castro Pinto e não uma mera representação de um ser específico. Fundado num ritmo existencial ("eles já no palco e eu ainda no camarim"), o poema sugere um processo reiterativo, fotograficamente, que reproduz uma realidade fugidia e incorpora uma consciência acusativa que tende a desqualificar e a esvaziar o sentido de ser do poeta.

A partir desta perspectiva, vemos que, na modernidade, não há destruição da aura como queria Benjamim. Há sim, um novo tipo de sagração motivada pela imediatez da técnica que leva o homem a produzir algo que ultrapassa o cotidiano. Neste novo estado de criação, o poeta já não tem consciência acerca de si. E essa é uma marca forte da modernidade: a descoberta dos limites existenciais do homem em que a existência é concebida como ficção, conforme sugere a última estrofe de "atos falhos". O mesmo se pode ver no poema transcrito abaixo:

poeta $\mathrm{x}$ poema

nem sempre o poeta

ronda o poema como uma fera a presa.

às vezes, fera presa e acuada

entre as grades do poema-jaula,

doma-o o chicote das palavras.

Considerando que o ato criador é um processo, sua primeira dimensão implica na imprevisibilidade. O poema tem o tom de uma profissão de fé marcada pela aventura de quem mesmo, sabendo da necessidade de um preparo cuidadoso para uma jornada 
poética a fim de dar essência ao poema, não sabe, o poeta, o caminho no qual é lançado, posto que, vê-se desafiado pelo próprio poema. O poema, antes dependente do poeta, agora apresenta-se autônomo, incomoda o poeta ao ponto de chicoteá-lo as palavras. O poema ressalta a possibilidade de, partindo das diferenças entre produtor (poeta) e produto (poema), se pode chegar a um jogo dialético onde não haverá um afastamento, mas uma agregação de um no outro, de forma que se perceba como o "outro, o longínquo é também o mais próximo e o mesmo" (Foucault, 1992:320).

Já no poema "escrever/não escrever" o aspecto de fabricação da realidade se percebe na intelectualização da sensibilidade e na reflexão crítica reforçada pelo conteúdo metalingüístico do texto que perpassa o poema:

Escrever/não escrever

escrever é um suicídio branco.

um consumir-se no fogo brando das palavras.

não escrever, um suicídio em branco

um consumar-se sem metáforas.

Ao considerarmos a atitude poética de Castro Pinto semelhante a de um fotográfico que prima pela "estandalização" temporal, há de se considerar que as sensações de limitação e finitude vivenciadas pelo poeta fortalecem seu impulso fotográfico para aglutinar momentos passados, presentes e futuros no interior do poema. Neste sentido, o tempo, na poética em questão, quando é tomado como elemento poético, não é tomado precipitadamente. Ao contrário, sua elaboração lenta, gradativa, meticulosa através de outros elementos ligados a ele, vai se casar perfeitamente com o olhar câmera que move o poeta, de início a fim, e lhe oferece uma oportunidade de fugir, pela abstração da revelação, da natureza fechada, asfixiante que o cerca. No poema “o homem revela a memória da máquina" é perceptível essa performance poética.

O homem revela a memória da máquina 
Da máquina

O homem revela a memória

E o que estava dentro

Revela-se ao lado de fora.

Da máquina

Pululam crinaças, peixes,

Sorrisos, elefantes...

E tornar-se coisificado

O que era abstrato antes.

Da máquina, no laboratório (escuro),

Pulam manhãs

E dóceis se misturam

Crianças, tigres e rãs.

Há, neste poema, uma determinação em registrar o momento presente. A "memória" que o "homem revela" se temporaliza ao ganhar movimento, ritmo próprio. O impulso do movimento opera a fusão entre tempo e espaço. Daí a consistência de elementos contrários: "dentro"/"fora", "coisificado"/"abstrato" que revelam o desejo de transpor um novo espaço-tempo definido. Na revelação da máquina é a essência viva da realidade (crianças, peixes, sorrisos) que permanece apesar de todas as transformações propiciadas no escuro do laboratório que conjugou harmonicamente num mesmo tempo-espaço "crianças, tigres e rãs".

Em outro poema "o homem conduzindo a máquina de fotografar", face à brevidade da vida, o poeta realiza uma abertura de possibilidades para o ser tornar-se apto à congelar instantes:

na máquina 
a paisagem é intestina

(o fora está dentro),

não pode mostrar-se ainda.

a máquina

guarda o que havia fora

e o homem a conduzindo

conduz duas memórias:

uma a da máquina (mais dentro)

e a outra a do homem (mais fora).

A valorização do instante flagrado pelas lentes da máquina é o trampolim para o aspecto atemporal sugerido na poética do autor. A presença dos verbos no presente, com exceção de "havia", coloca o poeta na posição demiurga de um fotógrafo. Trata-se de uma miragem que contém todo o potencial da existência de dois planos: o da máquina e o humano.

A partir deste rápido olhar na poética de Sergio de Castro Pinto, pode-se inferir que a produção poética do autor se insere no contexto da lírica moderna, no que ela tem de dissonante, anormal e obscura. Para Hugo Friedrich (1991), a negatividade da lírica moderna é marcada pela obscuridade que fascina e desconcerta, simultaneamente, e tem seus fundamentos na "dissonância e anormalidade" que atravessam o imaginário poético contemporâneo e cujas implicações são particulares a cada autor. A dissonância caracteriza-se pela "junção de incompreensibilidade e de fascinação, [...] pois gera uma tensão que tende mais à inquietude que à serenidade". A dissonância, pois, acaba por favorecer uma obscuridade intencional em confronto com a objetividade percebida nas relações sociais.

A anormalidade mobiliza no espaço poético um efeito de surpresa e de estanhamento tanto no leitor quanto no próprio poeta, para quem o "conhecimento do sentido daquilo que compôs é limitado". Embora seja um conceito complexo, posto que 
"suscita a impressão de que existe uma norma sempiterna", ao mesmo tempo, serve para confrontar as mudanças sensíveis ao longo da sucessão dos movimentos literários. Assim, para que a inquietação conquiste certo grau de expressividade, o poeta abeira-se das imagens e dos sentimentos "anormais". Dissonância e anormalidade configuram-se, pois, em opções poéticas que reforçam o contínuo mal-estar do ser poético com a sociedade.

Um terceiro elemento que caracteriza a obscuridade da lírica moderna é a acidentalidade, de onde emana a figura do transitório, idéia de temporalidade que bem se ajusta à vivência do que se propõe dissonante e anormal. Transitória e acidentada é a relação estabelecida entre o poeta e os fragmentos da realidade que ele próprio nomeia, mesmo que esteja em jogo o conflito de forças absolutas representantes do confronto do eu com a objetividade circundante. Isto posto, a obscuridade da lírica moderna coloca em evidência um sentimento do mundo marcado pelo negativo que acaba por engendrar as mais diversas identidades para a expressão poética.

Esses três elementos da lírica moderna quando relacionados à poética de Castro Pinto ainda que propiciem revelar um espetáculo de imagens representativas de um flagrante poético, deixam como rastro final a negação do sujeito. Nos poemas citados há uma série de evidências que reforçam a sensibilidade do poema e apontam para uma confluência entre o movimento das imagens e a atitude fotográfica do poeta. Enquanto poética representativa da era técnica, a produção de Castro Pinto expõe tanto a dramática consciência da condição humana em meio às formas desgastadas da vida moderna quanto revela a necessidade de congelar alguns instantes, mesmos que fugidios desta mesma condição. Dessa forma, transparecem as fraturas nas imagens do mundo e nas imagens do ser, a marca da perda, da falta de referências básicas do ser humano diante dos valores ditados pelas ideologias dominantes. Nessa crise de representatividade, Castro Pinto constrói sua poética fotográfica congelando imagens fugidias, buscando, assim, nessa atitude tecnicista recuperar o sentido da poesia. 


\section{REFERÊNCIAS}

BENJAMIM, Walter. A obra de arte na época de suas técnicas de reprodução. In: Textos Escolhidos. Trad. De José Lino Grünnewald... et al. $2^{\mathrm{a}}$ ed. São Paulo: Abril Cultural, 1983.

BERMAN, Marshal. Tudo que é sólido desmancha no ar. São Paulo: Companhia das Letras, 1986.

BOSI, Alfredo. O ser o tempo na poesia. São Paulo; Cultrix, 1993

FOUCAULT, Michel. As palavras e as coisas. São Paulo: Martins Fontes, 1992.

FRIEDRICH, Hugo. Estrutura da lírica moderna. São Paulo: Duas cidades, 1991.

PINTO, Sérgio de Castro. O cerco da memória. $2^{\mathrm{a}}$ ed. João Pessoa: Editora Universitária/UFPB, 2006. 


\section{O mergulho de Narciso: Os segredos da poesia em Susana Vernieri}

Nea de Castro (FURG)

RESUMO: Na poesia de Susana Vernieri há um "Narciso imprudente" que, muito além da autocontemplação, ousa mergulhar nas imagens fragmentárias do espelho. Nesta comunicação, tomo os reflexos ao modo das "Instantâneas", cenas móveis, fluidas, pelas quais Beatriz Sarlo procura captar nossa contemporaneidade. O corpus do trabalho é constituído por dois livros publicados por Vernieri: Memorabilia (2005) e De(s)amores (2007). Em seu universo, a poesia renasce: "Na morte do poeta se escuta o silêncio. / As teclas e as canetas/ sussurram o segredo/ para os que tiverem a coragem/ De querer ouvir".

PALAVRAS-CHAVE: Poesia brasileira - segredo - contemporaneidade.

ABSTRACT: There is a "reckless Narcissus", in the poetry of Susana Vernieri, who is deeply involved in the fragmented imagens of a mirror. In this presentation, I follow the concept of "Instant images" suggested by Beatriz Sarlo who attempts to catch our contemporaneity. This work is based on two books by Vernieri: Memorabilia (2005) and De(s)amores (2007). On her own words, the poetry emerges from: "On the poet's death, the silence is heard. / The keys and the pens/ whisper secretly / $t$ o those who are courageous enough to listen to it".

KEYWORDS: Brazilian poetry - secret - contemporaneity.

A poeta gaúcha Susana Vernieri (nascida em Porto Alegre, em 1965) revela seu paideuma - João Cabral de Melo Neto, Carlos Drummond de Andrade e Manuel Bandeira - nos dois livros do corpus desta comunicação: Memorabilia (2005) e De(s)amores (2007). Coloca assim sua poesia sob o signo do sincretismo da lira e da antilira, com liberdade para caminhar pelos desvãos, porões, e revelar ao leitor o inconfessável. Dialoga com os que celebram o desvio - Lord Byron, Gertrude Stein, Caio Fernando Abreu, Marisa Monte, entre outros - e com os materiais heteróclitos destes tempos: a cena literária, a que pertence também como doutora em literatura, condição comum a diversos poetas atuais; a imprensa, que conhece de dentro, como jornalista; e as cidades, que percorre como viajante, com suas vitrines, vias, caminhos, rios. Por tudo isso sua arte poética adquire matizes diversos, do tom acre, como de 
confissão entrecortada, a vozes mais leves e lúdicas, da atmosfera quase trash à reflexão elevada.

Em seu estudo exemplar, Sincretismo: a poesia da Geração 60 (1995), Pedro Lyra apresenta uma seqüência para a poesia do século XX no Brasil, à qual tenho recorrido em minhas pesquisas: Geração de 22, Geração de 45, Geração 60, e Geração de 80. A essas etapas, articuladas com base nas variantes de nascimento, estréia, vigência (que inclui, entre outros aspectos, o início do reconhecimento), confirmação e retirada, ele já agregava de modo antecipado o primeiro grupo de poetas no século XXI: a Geração-2000. Considero que Susana Vernieri pode ser identificada como parte da Geração de 80, embora sua estréia como poeta esteja deslocada para a etapa de vigência dessa geração.

Ela nasceu um ano depois da imposição da ditadura militar ao país. Como os demais autores da Geração de 80, foi se formando em meio aos efeitos do autoritarismo sobre o mundo cultural. Este se desenvolveu, sobretudo, por meio das tensões e diálogos entre as artes engajadas, que vinham desde os anos 60, e a expressão brasileira da contracultura mundial, o Tropicalismo, com origem na década seguinte. Ainda nos anos 70, como alternativa diferenciada dessas duas vertentes, surgiu a Poesia Marginal ou Poesia do Mimeógrafo. Na mesma década se disseminou o debate sobre o fim da era moderna que havia sido iniciado nos meados do século. À redemocratização do país correspondeu uma intensificação dos vínculos ao processo de globalização, com efeitos sobre a vida cultural. Em meio à ampliação e consolidação da Era Digital, os poetas que estudo se dispuseram então a recolher deslocamentos, fraturas e convocações da própria história da poesia como gênero, e da história local e dos demais países.

Penso que a obra de Vernieri, assim como todo meu corpus, pode ser classificada como poesia da hesitação. Essa expressão eu propus na tese de doutorado "O cânone da poesia brasileira em processo" (1998), orientada pela profa. Dra. Maria da 
Glória Bordini (PUCRS). Classifiquei então a obra de cinco dos dez poetas pesquisados por mim, como poesia da hesitação: Arnaldo Antunes, Augusto Massi, Alexei Bueno, Age de Carvalho, e Paulo Henriques Britto (Os outros cinco designei como autores da poética "do intermezzo", na expressão de Antônio Carlos Secchin (1996), entendida por mim como a passagem entre o modernismo e a poesia pós-moderna: José Paulo Paes, Lara de Lemos, Armindo Trevisan, Affonso Romano de Sant'Anna e Orides Fontela). Nos poetas hesitantes vi, sobretudo, uma pedagogia do paradoxo, pois a poesia perdera o discurso rigoroso que distinguia claramente a finitude, de que o modelo maior no século XX foi a arte engajada; e, num outro pólo, o discurso que permitia o sujeito lírico moderno desejar a "presença" do transcendente, de que o Drummond do "quarteto metafísico" - formado por Novos poemas (1946-1947), Claro enigma (1951), Fazendeiro do ar (1952-1953) e Vida passada a limpo (1954-1958) (MERQUIOR, 1976) - é o grande exemplo.

Ainda sob essa proposta de poesia da hesitação, a partir de 2002 iniciei junto ao Mestrado em História da Literatura (FURG) o meu Projeto "A lírica pós-moderna no Brasil", pelo qual venho estudando nossa produção contemporânea. À continuidade da leitura dos cinco autores vistos na tese, agreguei a de cinco outros autores - Rodrigo Garcia Lopes, Alckmar Luiz dos Santos, Adriano Espínola, Cláudia Roquette-Pinto, e Valdo Motta - e estou acrescentando agora Susana Vernieri. Nela já percebo, mais delineados, um tom emotivo e uma reflexão transcendente a partir do cotidiano globalizado, que se acoplam ao empreendimento metapoético próprio da Geração de 80 , ou seja, à escavação dela e de seus pares em interstícios, lacunas, fragmentos da linguagem.

Confissão e metaliteratura, autor e leitor, verso e reverso, imagem e reflexo, vida e morte, amor e ódio se entrecruzam no universo de Vernieri. A poesia nasce ali onde a morte parecia haver ceifado tudo, como sinaliza "Mergulho" (p. 34-35, em Memorabilia). A comovida e densa elegia em homenagem a Caio Fernando de Abreu (falecido em 1996) se desdobra em cinco estrofes. Nas duas estrofes iniciais o leitor é 
envolvido pelo sentimento da morte do poeta através das relações paradoxais onda/metade, dia/noite e deserto/verde. "Sopro" na primeira estrofe e "fronteira" na segunda talvez prenunciem que algo conflue e se gesta:

Na morte do poeta,

a onda quebra pela metade

e o encontro do dia com a noite

fica suspenso num sopro parado.

Na morte do poeta

se faz um minuto de deserto

no vasto verde da fronteira

É possível que no leitor se avolume o sentimento da impermanência, até por impacto visual (reforçado, no livro, pelos asteriscos antes e depois da estrofe), devido ao movimento de flash-back da terceira estrofe. Mas há, simultaneamente, essa denso diálogo entre solidão e água do rio, que pode sussurrar (sim, é esse o verbo, o leitor verá no movimento final da elegia) palavras, imagens, ainda não criadas, por serem criadas, no coração do leitor:

Um dia,

o poeta olhava as luzes refletidas na água do rio.

Na beira do rio, mãos para trás.

Na distância necessária do meio da festa.

Na noite da cidade, só. 
Nas duas estrofes finais é que o movimento transcendente amadurece: a morte do poeta pode fazer fronteira com a vida e a arte, no concerto de teclas, canetas, vozes, tempo. Mas é preciso que haja alguém (um outro poeta, um leitor) que acolha essas vozes através de um dar-se (mergulhar) profundo:

Na morte do poeta se escuta o silêncio.

As teclas e as canetas

sussurram o segredo

para os que tiverem a coragem

de querer ouvir.

Na morte do poeta,

as vozes param,

o tempo emudece

e o homem mergulha no rio.

Foi essa elegia que me propiciou uma das possíveis leituras de Memorabilia e De(s)amores. Nos dois livros, o ato de mergulhar pode ser visto como simbolização ora do intercurso entre água, nascimento e renascimento, ora dos elos entre arte, criação e recriação. Memorabilia é aberto em tom de segredo: a dedicatória é "Para.". A epígrafe apresenta uma citação de Drummond, como um guia para os paradoxos da arte da poesia: "Não cantarei o morto:/ é o próprio canto". Como prefácio, o estudo da poeta e teórica da poesia Maria do Carmo Campos, intitulado Nas cirandas do vivido: "Com as tintas daquela justa brevidade que assinala sólida vertente da poesia contemporânea, 
Memorabilia apresenta um lirismo preciso, ágil, lúcido, comovente. Intelectuais e sensoriais, os poemas miram o destino da escrita e os múltiplos meios que a envolvem".

Memorabilia traz, na folha de rosto, o título acompanhado de um subtítulo: São objetos pessoais do acervo de um escritor. A referência metaliterária conduz o leitor a tomar como itens desse acervo as cinco partes do livro: Letras, a que se integra a elegia Mergulho; Silêncios, Passos, Corpos, e Amor. Em Letras, o primeiro poema, intitulado "Ohlepse" (p. 16-17) já propõe ao leitor uma mudança de olhar, o reverso do espelho:

.otrever, otrevnl

?otriviD

.osrever,otnevnI

?osreviD

O jogo dos signos, que inclui a conversão feita pelo leitor para a linguagem diária, aponta para sentidos diferenciados da palavra poética. No primeiro diálogo do sujeito lírico com o leitor a "reverto" e "invento" ele contrapõe a indagação "Divirto?"; no segundo, a "reverso" o e "invento", quem lê é questionado por um "Diverso?". Há então o jogo de reverter, estabelecer o reverso, inventar, mas há também dúvidas sobre o alcance e natureza desse jogo. O desafio ao leitor, outra das marcas dos dois livros de poesia de Susana Vernieri, vai assumir um tom mais provocativo em "Lógica da inutilidade" ( p. 18-19) desde o preâmbulo: "De que adianta escrever poesia / se não entendes". No dístico final, as sentenças corrosivas: N"ão entendes, não lês, não pensas / Não escrevo".

É no segundo item de Memorabilia - Vitrine - que o leitor encontra o poema "Vitrine de souvenirs ou Memorabilia" (p. 22-24). Com ele, uma espécie de trégua poeta-leitor graças ao compartilhamento do "segredo" (eco da penúltima estrofe da elegia "Mergulho?") e dessa contemplação da poesia - eis aí a metafórica "vitrine de 
souvenirs" - feita de entrevisão e memória, de presença (livros, estantes) e lapsos, vazios ( sublinhados, paradoxalmente, pela lacuna visual entre a penúltima e última estrofes):

Ganhava livros de poesia,

olhava a infinidade das letras

expostas uma a uma ao lado das outras,

Olhava a natural diversidade

e, de certo modo,

percebia as sílabas.

Enchia as estantes

com a explosão de cores

das capas e das lombadas

e enfeitava a sala forrando

as paredes

como se toda ela fosse

uma vitrine de souvenirs.

Só não sabia o que eram versos,

nem descobria o segredo oculto

nas dedicatórias.

A leitura irá desvendando os itens seguintes - Silêncios, Passos, Corpos, para concluir em Amor, de que "Tambor" (p. 96-97) é uma peça emblemática do cantar amoroso de Susana Vernieri, feito sobretudo de confissão e versos lúdicos, de entrega e distanciamento:

O ritmo te intima

Te livra, te solta 
Dança comigo

Ao som do tambor?

Baila comigo

Sob a lua do equador:

The drum is the most important

Instrument

Meu coração bate por ti

E eu toco bumbo na banda

do colégio

De(s)amores expõe a letra s entre parênteses, como indicação performática das duas partes do livro: a primeira, Deamores, que apresenta, entre outros poemas, "Mergulho" e "Mergulho II"; e a segunda, Desamores, que traz contos, entre eles "O mergulho". Neste livro a poeta optou por colocar duas epígrafes: na de Deamores, o leitor acolhe o amor antitético, na citação de Camões: "Amor é um não querer mais que bem querer"; na de Desamores, a negatividade, o conflito atormenta o amor, na citação de Lord Byron: "Pois o ódio é, de muito, o prazer mais longo; os homens amam depressa, mas detestam devagar". Ao longo do livro, então, caminho através da experiência do amor como ambigüidade, exercício de máscaras, tal como a dedicatória: " A quem inspirou". Mas há momentos de certa paz e elevação, como em "De suspiros e versos" (p. 15), o primeiro poema de Deamores. Pelo amor a persona lírica está religando arte e Deus. Está em "suspenso", por um instante, a inquietação, embora ela ronde nas aliterações nasalizadas da própria palavra "Suspenso" e em "Latente", "fino", "pungente", e "Crente":

Frágil é o suspiro de Deus

Suspenso no ato de amor 
CASTRO, N. 0 mergulho de Narciso: os segredos da poesia em Susana Vernieri

Ele fica no ouvido presente

Latente, fino, pungente.

Ágil é o verso simples

Escrito em silêncio

Ele fica impresso sem preço

Vivo, limpo, doce.

Crente.

A poesia está escrita em silêncio, em Susana Vernieri. Por isso tudo se desdobra: o positivo está feito de negativo, este por aquele; não se trata de dualidade, mas sim de simultaneidade, como em "Beijo" (p. 17) e sua única estrofe:

Todas as tesouras

O fio

Lâmina voraz

Eu sangro no corte

Da tua boca na minha boca

Metalinguagem e amor estabelecem interconexões, trocas, na exposição do paideuma em "O meu amor" (p. 31):

O meu amor ascende na espinha

Lembra verso de Drummond

É festa com bandeirinha

Pois rodopio em fogueiras faceira

Salto do chão como em noite de São João 
CASTRO, N. 0 mergulho de Narciso: os segredos da poesia em Susana Vernieri

O meu amor recende a incenso

Dele penso em Bandeira

No rio profundo correndo dentro de mim

Cheiros de jasmim

Alecrim

O meu amor pressente Cabral

É de cimento e cal

De pedra, areia, ampulheta,

Areal.

No canto de Vernieri o amor é então movimento criativo, construtivo, mas pode se tornar também experiência de dor a ser assimilada. Em ambos os casos, propicia matéria autorreflexiva para a poeta. Em De(s)amores, percebo no poema "Mergulho" (p. 28) um diálogo intertextual em relação a um conto de fadas dos Irmãos Grimm, "A Gata Borralheira". A mulher vive uma perda, mas à diferença da personagem canônica, ela não reassume o cotidiano após as doze badaladas, pois deseja acolher seu trauma. Transcrevo todo o poema:

Com um colar de coral e um copo de cristal celebro o adeus

A bebida não importa

Pode ser até suco de laranja

Salto alto, maquiagem, vestido de festa

Quando bate meia-noite a cama está pronta para um

mergulho

Não tiro a jóia

Pois quero sonhar com tubarões 
Em "Mergulho II" (p. 36) a persona lírica diáloga com um Narciso que mergulha "no reflexo do espelho" para "sair limpo" de si mesmo. Mesmo sendo cúmplice desse "Narciso sorridente, inocente", tenta dissuadi-lo do mergulho existencial, com o argumento da autocontemplação:

É melhor sucumbir

Ao namoro de teus olhos,

Narciso imprudente, inocente

O que pensas encontrar?

Vais em busca de um par?

A seguir, no entanto, o diálogo se completa com a cumplicidade inteiramente restabelecida:

É bom carregar pouco peso

Para quem sabe voltar

Para sair limpo

Para não ficar preso

Nas profundezas do espelho

No conto "O mergulho" (p. 85-87), o narrador em primeira pessoa é o protagonista Alberto, que realiza uma trajetória de aprendizado, simultaneamente, de liberdade e amor. Ele não sabe nadar e teme qualquer espelho d'água, mais ainda o mar. Como quase morrera afogado uma vez, sendo levado por uma onda, obedecia a seu pânico. Ana o convence graças a sua aceitação da dor existencial: "Eu já morri afogada em lágrima" (p. 86) e porque lhe promete revelar um segredo. Alberto, que se chamara a si mesmo de "pedra" (id.), conta na parte final:

Há um tesouro escondido no fundo do mar. Uma pedra raríssima que Ana sabe onde se encontra. Uma pérola preciosa, uma jóia moldada pela vida. Colhemos o presente e voltamos à superfície. A praia nos espera com seu sol menos doloroso. Estamos limpos e carregando uma pedra preciosa na mão. (p. 87) 
Vejo na poesia de Susana Vernieri e em seus ecos no conto um "Narciso imprudente" que, muito além da autocontemplação do Narciso mítico, ousa mergulhar nas imagens fragmentárias do espelho. Nesta comunicação, tomo os reflexos ao modo das "Instantâneas", cenas móveis, fluidas, pelas quais Beatriz Sarlo procura captar nossa contemporaneidade. A teórica argentina fala sobre seu método de examinar o detalhe: "são registros 'fotográficos' de experiências na cultura contemporânea, experiências diretas, voláteis, e, em alguns casos, esboçadas ante meu próprio olhar" (1996:7). Os poemas e a narrativa, como percepções - reflexos do espelho - do ato de mergulhar, são "Instantâneas" que oferecem ao leitor insights da experiência existencial, amorosa e de arte poética. Há uma busca de sair "limpo", e conseguir de fato o tesouro buscado, como na história do par Alberto-Ana, mas há também uma perspectiva tênue, indecisa, um "quem sabe" voltar. Sujeitos diferentes se dispõem, um, a mergulhar para o encontro com o obscuro de si mesmo, seus tubarões, num rito ambíguo, que se comemora por meio de "copo de cristal", mas com " até suco de laranja". Outro, a se atirar no rio e assim reatualizar, através e além do silêncio, a experiência da poesia.

Todos que lemos poetas atuais tendemos a ser cautelosos, como Alexei Bueno que fala, em seu livro Uma história da poesia brasileira, na montagem de um "guia sutil e móvel para o leitor" (2007:396). Ou Manoel da Costa Pinto, que explica ter feito sua Antologia comentada da poesia brasileira do século 21 mais na perspectiva do "leitor que vê na poesia um organismo vivo, em constante mutação, sujeito a avaliações no calor da hora, juízos provisórios e apostas" (2006:9). Pois que aí está em nossa cena literária a poesia de Susana Vernieri: com cuidado e atenção, escutemos seus segredos. 


\section{BIBLIOGRAFIA}

BUENO, Alexei. No agora e aqui pouco sabido. In: . Uma história da poesia brasileira. Rio de Janeiro: G.Ermakoff, 2007. p. 396-407.

LYRA, Pedro. Sincretismo: a poesia da Geração 60: introdução e antologia. Rio de Janeiro: Topbooks, Fundação Rioarte; Fortaleza: Fundação Cultural de Fortaleza, 1995.

MERQUIOR, José Guilherme. Verso universo em Drummond. Rio de Janeiro: J. Olympio, 1976.

PINTO, Manuel da Costa. Antologia comentada da poesia brasileira do século 21. São Paulo: Publifolha, 2006.

SARLO, Beatriz. Instantáneas: Medios, ciudad y costumbres en el fin de siglo. Buenos Aires: Espasa Calpe, 1996.

SECCHIN, Antonio Carlos. Poesia e desordem: escritos sobre poesia \& alguma prosa. Rio de Janeiro, Topbooks, 1996.

VERNIERI, Susana. Memorabilia. Porto Alegre: Libretos, 2005. . De(s)amores. Porto Alegre: Editora do Autor, 2007.

\section{NOTA}

$1 \mathrm{O}$ Resumo, incluindo as citações da poesia de Susana Vernieri, foi traduzido pela Profa. Ms. Rossana de Felippe Böhlke (FURG). 